Green, E.G.T., \& Staerklé, C. (2013). Migration and multiculturalism. In L. Huddy, D.O.

Sears, \& J.S. Levy (Eds.), Oxford Handbook of Political Psychology (2 ${ }^{\text {nd }}$ ed., pp. 852-889). Oxford, UK: Oxford University Press.

\title{
Migration and Multiculturalism
}

\author{
Eva G.T. Green \& Christian Staerklé \\ University of Lausanne, Switzerland
}

“Multiculturalism has utterly failed”, German Chancellor Angela Merkel declared in October 2010, “immigrants need to do more to integrate in German society”. A few months later, in February 2011, British Prime Minister David Cameron also condemned his country's long-standing policy of multiculturalism as a failure, claiming that many young British Muslims were drawn to violent ideology because they found no strong collective identity in Britain. These two quotes from leading European politicians exemplify how migration and multiculturalism have become key issues in contemporary societies. Virtually all countries in the world need to deal with the steady flow of people crossing international borders that have made societies in our globalized world more and more diverse. Despite its contested nature as a normative model for organizing diversity in receiving societies, multiculturalism has become an inescapable reality to which countries need to adapt.

This chapter is concerned with two major questions concerning migration and multiculturalism. First, it looks at the social and psychological processes at work in the migrant experience. Second, it deals with how members of receiving societies react to the increased and diversified immigrant presence in their societies. ${ }^{1}$ Our review draws mainly upon research and theory in political and social psychology. Reflecting the diversity of classic and recent empirical work on migration and multiculturalism, we present research covering a 
wide range of methodological approaches, including survey, experimental and qualitative studies. The chapter emphasizes how historical and political contexts affect the nature of intergroup relations between migrant groups and receiving societies. It furthermore highlights the role of widely shared social representations in processes of migration and multiculturalism, expressed in ideological belief systems, political discourse and everyday cultural repertoires. We argue that a political psychology perspective to migration and multiculturalism will gain from taking a interdisciplinary approach in which different levels of analysis—including individual, group and societal factors—are combined and articulated (Castles \& Miller, 2009; Chryssochoou, 2004; Deaux, 2006; Verkuyten, 2005a).

The chapter is organized in four parts. The first part outlines some historical benchmarks of modern migration and briefly presents two key notions of a psychological approach to migration—assimilation and multiculturalism—in their historical context. In a second part, we summarize empirical research that focuses on the psychological dynamics involved in the migrant experience, in particular the interactionist and complex nature of migrant identities, acculturation and adaptation in receiving societies, and intergroup approaches to acculturation and multiculturalism. The third part analyses the role of threat regarding immigrants and immigration in the reactions, attitudes and beliefs of majority populations in receiving societies. The fourth part presents recent multilevel research on the effects of contextual factors on attitudes towards immigration held by national majority groups.

Since other chapters in this volume are directly concerned with processes related to historical ethnic minorities within countries, this chapter specifically analyses diversity and multiculturalism as the outcome of international migration. Moreover, although migration is a global phenomenon, we focus our discussion mainly on those migration flows which end up in Western countries since it is mostly in these contexts that empirical research has studied the 
psychological processes involved in the migrant experience and the public reactions to immigration.

\section{ASSIMILATION AND MULTICULTURALISM IN CONTEXT}

Early works on immigration and incorporation of immigrants (e.g., Park \& Burgess, 1921; Thomas \& Znaniecki, 1918) reflected questions arising from voluntary and permanent forms of migration, especially to the U.S.. Incorporation of immigrants in the host society was seen as a one-way street towards the hegemonic White Anglo-Saxon Protestant "WASP" norm in which immigrants gradually lose their ties with their country of origin while picking up the values of the receiving society (Kivisto, 2002). In this model of migrant assimilation, the identity of origin was to be replaced with the host identity, and ethnic distinctions as well as the cultural and social practices that express it were bound to disappear (see Alba \& Nee, 2003, for a contemporary analysis of assimilation). Assimilation therefore relies on the principle of similarity between migrant groups and the receiving society: Such intergroup similarity is deemed to foster successful integration into mainstream society and to promote harmonious intergroup relations within receiving societies. Largely taken for granted in the early times of immigration, it was the sole conceivable form of migrant incorporation. The “melting-pot” of American society was for a long time the key metaphor to figuratively describe assimilation, referring to the dissolving of various ethnic and national identities into a new cultural identity.

European diversity, in contrast, is historically due to migration from former colonial countries and the presence of different cultural and linguistic groups on national territories, for example Wallonian and Flemish populations in Belgium, or Finnish- and Swedishspeaking and native Sami populations in Finland. In 'multi-nation' states where cultural diversity arises from the incorporation of territorially concentrated cultures into a larger state, 
the political debate has been more concerned with political rights of resident cultures than with their assimilation into receiving societies (Kymlicka, 1995). In these contexts, minority cultures typically claim self-government rights that demand some form of political autonomy (e.g., the province of Quebec in Canada) or special representation rights in order for the groups' views and interests to be effectively represented in the political process, for example by reserving a certain number of seats in the legislature for members of minority groups.

After WWII, the nature of international migration gradually changed. Migration volume increased drastically, due to armed conflicts and large-scale natural disasters, growing global inequalities pushing people to search for a better life, or new international agreements liberalizing person movements (Castles \& Miller, 2009). The U.S. was confronted with new waves of mass immigration from Latin America (especially Mexico), Asia and the Caribbean after the Immigration Act of 1965. This migration was characterized by unprecedented numbers of undocumented "illegal” immigrants, by religious identities different from those of American mainstream society, by a tendency to maintain closer ties with their countries of origin, and often by a reluctance or incapacity to learn the English language. Thus, in the $21^{\text {st }}$ century, migrants originate from increasingly diverse economic, social and cultural backgrounds, giving rise to differentiated forms of migration in receiving countries, including voluntary and involuntary migration, temporary and permanent labor migration, as well as refugee, asylum seeker and family reunion migration. Migration has also become increasingly politicized, in particular with respect to domestic politics which are ever more marked by public debates about immigration, by the tendency of political parties in the Western world to define their identity through tough stances towards migration and multiculturalism, and by hostile and xenophobic attitudes of large segments of national majority populations in receiving societies (Kivisto, 2002). The classical understanding of assimilation as a general settlement policy has therefore become ever more questioned. In this context of "new 
immigration”, immigrants can no longer be seen as definitely leaving their country of origin or permanently taking residence in the receiving society, the receiving society cultures have become too heterogeneous to provide a single cultural model towards which immigrants should strive, and in light of the difficult experiences of increasing numbers of immigrants the notion of inevitable assimilationist progress has become untenable (Deaux, 2006).

The response to the limitations of an assimilationist view of migrant incorporation was the gradual development of “difference”-based conceptions of citizenship, based on the formal recognition of migrant and other minority identities and legal accommodation of their difference (Isin \& Wood, 1999; Taylor, 1992). One of the major models of this differentialist turn (Brubaker, 2001) was multiculturalism, a term which covers multiple realities and presents a number of ambiguities (Glazer, 1997). In a descriptive sense, multiculturalism refers to the diverse ethnic make-up of contemporary societies, be they the product of existing ethno-cultural groups within countries or the outcome of international migration. In this sense, virtually all countries in the world are multicultural. In a normative and prescriptive sense, in turn, multiculturalism is a desirable way of organizing diversity within a country. Offering a positive view of cultural identity maintenance, it considers that cultural diversity as such has positive effects on a society, by contributing fresh perspectives, promoting openness towards others and preventing discrimination (Kymlicka, 1995).

Multiculturalism is implemented with legal and political dispositions that accommodate claims for the recognition of group-specific identities, for example rights for political representation, legal protection of cultural practices, or language and educational rights (see Licata, Sanchez-Mazas, \& Green, 2011, for a social psychological recognition approach of immigration and prejudice in Europe). Such group-differentiated policies formally recognize the legitimacy of differences between ethnic and cultural groups residing in a country and aim at promoting equal treatment and equal rights of these groups 
(Kymlicka, 1995). The passionate debates about the legitimacy of civil, social, or political rights of specific migrant groups, for example affirmative action policies or group-specific clothing regulations (e.g., concerning headscarves and veils of Muslim women, Joppke, 2009) reveal that the question of group rights is one of the most pressing issues in contemporary societies struggling with multicultural demands (Ingram, 2000; Koopmans, Statham, Giugni, \& Passy, 2005).

Much like assimilation, the normative model of multiculturalism has also become increasingly under pressure (see Bloemraad, Korteweg, \& Yurdakul, 2008, for an overview). Multiculturalism is accused of undermining national cohesion, of exacerbating intergroup divisions rather than overcoming them, of essentializing and reifying group boundaries, and ultimately of compartmentalizing ethnic groups into segregated urban ghettos (Barry, 2001). As a result, multiculturalism would fuel negative attitudes towards migrant groups rather than alleviate them. Such disillusionment with multiculturalism is also observable on the political level, as illustrated by our opening quotes from Angela Merkel and David Cameron. There is today increasing evidence of a backlash against multiculturalism, at the level of public opinion, political discourse, immigration policy and political theory (Castles \& Miller, 2009). Brubaker (2001), for example, observes the rise of new forms of assimilation policies that no longer expect immigrants to be completely absorbed in the receiving society. These policies place a stronger emphasis on the progressive process rather than on the desired end-state of becoming similar to the receiving society, for example in the form of proposed or encouraged language courses for immigrants or in the easing of strict naturalization rules. As a result, many countries which formerly had a strong policy emphasis on multiculturalism such as the Netherlands, Sweden and Australia have shifted to policies that require more "adaptation” and “integration” from immigrants, often under pressure of rising right-wing populist parties (Joppke, 2007). 
The emergence of transnational and diaspora communities is another key feature of contemporary migration (Faist, 2009; Kivisto, 2002; Portes \& Rumbaut, 2006). Owing to new modes of online communication and decreasing travel costs, migrants more easily maintain relationships with their societies of origin across national borders. Transnational social spaces are expressed in political engagement of migrants in their country of origin, as financial support for homeland networks, or as regular travelling between the receiving society and the country of origin. Transnationalism thereby de-emphasizes the importance of physical location of migrants in the receiving society and extends multiculturalism and ethnic loyalties across the national borders of the receiving society.

So what is left when the two major paradigms of migrant incorporation-assimilation, based on the principle of intergroup similarity, and multiculturalism, based on the principle of intergroup difference-are both questioned in contemporary societies? A first answer to this question is provided by the meanings migrants themselves give to their experiences in a receiving society and the strategies they enact to construe their migrant identities.

\section{THE MIGRANT EXPERIENCE}

\section{Contemporary Migrant Identities}

The concept of ethnic identity captures the dynamics that are involved in the negotiation of cultural and ethnic boundaries in receiving societies (see Verkuyten, 2005a). Ethnic identities involve beliefs in commonality, shared kinship or ancestry; they are historically defined and involve a sense of temporality and continuity which sets them apart from other social identities (see Sani, 2008). Yet, in contemporary research, ethnic groups are not bounded cultural entities to which people naturally belong, but are rather social constructions that emerge from continuous social interactions between the migrant and the majority group and within migrant groups themselves (Barth, 1969). Migrant identities are 
therefore the product of both 'other-definition' and 'self-definition'. ”Other-definition means ascription of undesirable characteristics and assignment of inferior social positions by dominant groups. Self-definition refers to the consciousness of group members of belonging together on the basis of shared cultural and social characteristics. The relative strength of these processes varies. Some minorities are mainly constructed through processes of exclusion (which may be referred to as racism) by the majority. Others are mainly constituted on the basis of cultural and historical consciousness (or ethnic identity) among their members.” (Castles \& Miller, 2009, p. 33). As a consequence of this interactionist view, ethnic group boundaries may be legitimized and maintained (as in multicultural discourses) or on the contrary challenged and eventually dissolved (as in assimilationist discourses). The disappearance of formerly important distinctions, for example between Irish immigrants and American mainstream society (Ignatiev, 1995), illustrates how boundaries of ethnic groups may be transformed and their meaning reassessed.

The negotiation of migrant identities within ethnic groups concerns for example normative pressures to conform to ingroup obligations (such as the maintenance of cultural traditions) and outgroup expectations (such as labor market integration). These negotiations may take place between first- and second-generation immigrants, between parents and children, or between high- and low-status group members (Wimmer, 2004). As a result, any characteristics, beliefs or practices associated with ethnic groups may change over time, for example when longstanding traditions are replaced with modern customs. This emphasis on within-group variation and the active self-construal of ethnic groups is an antidote to widespread views of migrant groups as homogenous entities and helpless victims of majority discrimination (see Brubaker, Feischmidt, Fox, \& Grancea, 2006).

Ethnic identification, that is, the subjective importance of membership in an ethnic group, has been shown to be particularly strong for migrant groups in receiving societies in 
which the legitimacy of their norms and values — and even their mere presence on national soil—is questioned. In a study on religious identification by Muslim (Sunni) migrants in the Netherlands, Verkuyten (2007) found that over half of the participants had the highest possible score on scales of religious identification. For these "total” identifiers, identification with the receiving Dutch society was lower than for those Muslims with lower levels of religious identification. These findings suggest that Muslim migrants are prone to stress their ethnic identity in a context of increasing tensions with the receiving society. The degree and nature of ingroup identification with migrant groups thus depends on the specific intergroup configurations in receiving societies. Migrants differentially construe their ingroup identities as a function of the intergroup relations with national majorities (Hopkins \& Kahani-Hopkins, 2006). Hence, ethnic identifications by migrant groups are flexible and change as a function of the intergroup context in receiving societies.

In contrast to classical intergroup research in social psychology which treats social categories as unproblematic and defines them with unambiguous boundaries, migrant identities are often "messy” and group boundaries "blurry” (Alba, 2005), especially those of second-generation immigrants (see Lamont \& Molnar, 2002). The variety of migration contexts, in terms of countries of origin and receiving societies, of migration history, of duration of residence and political grievances, gives rise to a wide range of possible migrant identity configurations and forms of interdependence between migrant groups and receiving societies. Contemporary migrant identities combine cultural origins in different ways and thus give rise to new and complex identities, described as multiple, mixed, hybrid or hyphenated identities (Ashmore, Deaux, McLaughlin-Volpe, 2004; Chen, Benet-Martinez, \& Bond, 2008; Phinney, 1990; Verkuyten; 2005a; see also Huddy, Chapter 25).

The issue of category labeling captures the often difficult task of using appropriate names for migrant categories whose status in the receiving society is changing. Category 
names are malleable and strategic constructs. Category labels make a statement about the norms, values and cultural history of the group, and they convey a sense of position of the group in the larger society (Reicher \& Hopkins, 2001). Examples include the continuous debate about the use of "Latino”, "Hispanic” or hyphenated category labels (e.g., "MexicanAmerican”) to describe immigrant groups of Spanish and Portuguese descent in the U.S. (Deaux, 2006; Portes \& Rumbaut, 2006) or the shift in usage from "Negroes" to "Blacks" to “African-Americans” (Philogène, 1999).

One of the striking features of migrant identities is the often huge gap between the way migrant groups are categorized by national majorities and by migrant groups themselves. National majority discourse appeals to inclusive and generalizing categories with often negative connotations such as “foreigners” or “immigrants” (Kosic \& Phalet, 2006), while migrants themselves use more fine-grained and less inclusive categories, distinguishing for example between different religious orientations, national and regional origins, or first-, second-, and third-generation immigrants. In a study based on a discursive approach to social identity theory, Hopkins and Kahani-Hopkins (2004) illustrate how widespread majority representations of a homogeneous and unified Muslim category are challenged by Muslim activists in Britain: some activists put forward a political understanding of Muslim identity and restrict the boundaries of Muslim identity to those members who conform to central Muslim practices such as the Hajj (the Mecca pilgrimage) or the daily prayers. Others, in contrast, promote a more inclusive and spiritual view of Muslim identity and feel affiliated with “people [throughout the world] who are struggling to have their voices heard” (p. 53). In another study, Hopkins and Kahani-Hopkins (2006) contrasted two views by Muslim representatives on intergroup contact and Islamophobia. One view sought to rectify widespread negative attitudes towards Muslims through raising awareness of variation within the Muslim group and challenging prevalent views about the fundamentally antagonistic 
nature of relations between Muslims and Westerners. The other view was more polemic and suggested that Islamophobia was a struggle between falsity and truth and between unbelief and belief, thereby urging Muslim community members to unite and enter into negotiations with the non-Muslim other with a single voice. Similar variation was observed in a survey study among more secular and less identified Turkish Alevi Muslims and more religious and highly identified Sunni Muslims in the Netherlands (Verkuyten \& Yildiz, 2009). The point here is that migrant identities are actively construed and contested both from within the migrant groups themselves and from the outside, through majority discourses on Muslim and other migrant groups.

Discursive research contextualizes migrant experiences within particular social settings and analyzes migrant identities as flexible and dynamic resources, showing how they change as a function of both social situations and the historical and political context of receiving societies. The analysis of situated discursive practices thus enables a detailed analysis of the subjective understanding of the migrant experience, such as an unfavorable social status of migrant groups or the suffering of discrimination (Deaux, 2006; Verkuyten, 2005c). Studies have for example analyzed how migrants reconcile multiple identities or how demeaning representations associated with ethnic minority neighborhoods (Howarth, 2002), pervasive discrimination (Hopkins \& Kahani-Hopkins, 2006) and historical collective memories (Ali \& Sonn, 2010) shape the construction of migrant identities.

Another key aspect of migrant identities concerns their relationship with the political involvement of migrants. Research has investigated the role of politicized migrant identities as determinants of collective action associated with migrant group membership, including social movements in favor of migrants' position in society and civil society participation in associations defending the rights of migrant groups (see Azzi, Chryssochoou, Klandermans, \& Simon, 2010). In a longitudinal survey study on Turkish migrants in Germany, for 
example, Simon and Ruhs (2008) showed that dual identification with the Turkish migrant group and the superordinate German national group uniquely predicted political involvement in the form of support for political claims in favor of Turks living in Germany, while no relation was found between dual identification and radical or violent politicization. These findings suggest that while identification with the aggrieved ingroup is necessary to foster involvement on behalf of the ingroup (Spears, Jetten, \& Doosje, 2001), identification with the superordinate group is also required to foster normative collective action, since it reflects the acknowledgement that political action needs to be taken within the limits of general acceptance of the larger polity (see Klandermans \& van Stekelenburg, Chapter 26, for dynamics of political mobilization by migrant groups).

\section{Acculturation and Adaptation of Migrants}

Acculturation research focuses on the determinants and consequences of different strategies migrants employ to adapt to new cultural milieus. It has its roots in cross-cultural psychology and studies the individual- and group-level changes resulting from intercultural contact (see Sam \& Berry, 2006). The classical definition states that acculturation refers to "those phenomena which result when groups of individuals having different cultures come into continuous first-hand contact, with subsequent changes in the original culture patterns of either or both groups” (Redfield, Linton \& Herskovits, 1936, p. 149).

The most influential model of acculturation has been proposed by Berry (1990). His model emphasizes the bi-dimensional nature of acculturation processes where the maintenance of relationships with one's country of origin and the development of new ties with the receiving society are independent of each other and may therefore combine in different ways. Four basic types of acculturation strategies result from crossing these two dimensions: integration reflects a desire to simultaneously maintain ties with the country of 
origin and establish strong contacts with members of the receiving society, whereas separation denotes the wish to maintain one’s migrant identity while minimizing contacts with the receiving society. Assimilation refers to the abandonment of one's original cultural identity and the pursuit of contacts with the receiving society, whereas marginalization describes the rejection of both the original culture and the receiving society.

More recently, Berry's model has been extended into the Interactive acculturation model (IAM, Bourhis, Moïse, Perreault \& Sénécal, 1997; Bourhis, Montaruli, El-Geledi, Harvey \& Barrette, 2010). This model adds to the acculturation orientations adopted by migrant groups the acculturation expectations held by members of receiving society towards specific groups of immigrants. Members of the receiving society may for example expect immigrants to fully abandon their original culture and follow an assimilation strategy. The IAM thus recognizes that not only the immigrants, but also the receiving society may undergo transformations as a result of the arrival of immigrants (as already implied in the original definition of acculturation), thereby emphasizing the intergroup nature of acculturative processes. The IAM further adds individualism as an alternative strategy to marginalisation, denoting an orientation which stresses personal characteristics rather than group membership in both migrant and receiving society acculturation orientations. The IAM also highlights the fact that integration policies adopted at the national, regional, and municipal levels of government can both reflect and influence the acculturation orientations adopted by receiving society and migrant communities.

A large body of research has investigated the individual and social factors which determine the preferences for any one of these acculturation strategies. Studies find that integration (e.g., Berry, 1990; van Oudenhoven, Prins, \& Buunk, 1998) and separation (e.g., for Turks in Germany, Piontkowski, Florack, Hoelker, \& Obdrzalek, 2000) are the preferred modes of acculturation for minorities. Majorities, in turn, expect migrants to endorse either 
integration or assimilation strategies (Ryder, Alden, \& Paulhus, 2000; Zagefka \& Brown, 2002; Roccas, Horenczyk, \& Schwartz, 2000; Nesdale \& Mak, 2000), though exceptions to these patterns are not uncommon. A number of factors have been shown to account for the endorsement of acculturation expectations by majorities, including strength of ethnic and national identification, ethnocentrism, social dominance orientation, political orientation, feelings of threat from the presence of migrant groups, individual networks of ethnic contacts, or perceptions of immigrant discrimination (e.g., Bourhis, Barrette, El-Geledi, \& Schmidt, 2009; Montreuil, Bourhis, \& Vanbeselaere, 2004). Furthermore, acculturation expectations adopted by majorities depend on the type of migrant groups: Integration is likely to be the preferred strategy for "valued” minorities (in terms of favorable stereotypes associated with them), while assimilation, segregation and marginalization are more likely to be endorsed for negatively evaluated minorities (Montreuil \& Bourhis, 2001).

Nevertheless, the fourfold typology of general acculturation orientations has been criticized for potentially obscuring the wide array of possible forms of interdependence between migrant groups and the receiving society. Migrants' choice of acculturation orientation has been shown to depend on how the relationship between the migrant group and the receiving society is operationalized; whether migrants were asked about willingness for contact with the majority group, adoption of majority cultural values, or identification with the majority group, differently affected their endorsement of acculturation strategies (Snauwaert, Soenens, Vanbeselaere, \& Boen, 2003). These varying operationalizations thus reflect different degrees of closeness and different levels of involvement with the receiving society, thereby highlighting the difficulty of defining unambiguous criteria of intergroup similarity, an issue already recognized by Gordon (1964) who differentiated multiple (e.g., cultural, linguistic, behavioral, attitudinal or identity) dimensions of assimilation. Not 
surprisingly, then, the rather general measures of endorsement of different acculturation strategies are also controversial (e.g., Arends-Tóth \& Van de Vijver, 2006).

Studies have also examined the factors which determine whether acculturation is successful or not, that is, whether migrants are able to appropriately negotiate the demands of the receiving society and adapt to a new cultural context. Successful long-term adaptation is multidimensional and evidenced with migrants' sociocultural and political integration, labor market integration, psychological well-being and physical health. Cultural learning approaches highlight the necessity to learn culture-specific skills in order to successfully adapt to a new cultural milieu, in particular communication competence such as proficiency of the language of the receiving society (Jasinskaja-Lahti, 2008) and effective social interaction skills (Masgoret \& Ward, 2006). Acculturative stress may result from unsuccessfully negotiated cultural contact and manifest itself as depressive symptoms, feelings of anxiety and psychosomatic disorders (Berry, 2006). Research has generally shown that integration is the most and marginalization the least adaptive strategy to deal with acculturative stress, the integration strategy leading to the most positive outcomes in terms of coping, psychological health and well-being (Berry \& Sabatier, 2010). Yet, processes of adaptation develop over time, with acculturative stress increasing soon after the arrival of the migrant in the receiving society, followed by a decrease over time (Berry, 2006).

A key factor that determines the chances of successful adaptation is the experience and perception of discrimination by migrants. There is ample empirical evidence showing that perceiving oneself as a target or victim of majority discrimination is a major acculturative stressor, increasing depressive symptoms, distress and anxiety (Cassidy, O'Connor, Howe, \& Warden, 2004; Finch, Kolody, \& Vega, 2000; Liebkind \& Jasinskaja-Lahti, 2000) and decreasing life satisfaction, well-being and self-esteem (Vedder, Sam, \& Liebkind, 2007). However, in line with the common finding that threats to the ingroup encourage group 
identification, perceived discrimination has also been shown to increase ingroup identification (Jetten, Branscombe, Schmitt \& Spears, 2001). As a result, the deleterious effects of perceived discrimination may to some extent be buffered through identification with minority groups (see Schmitt \& Branscombe, 2002). Furthermore, extensive social support increases migrant well-being and adjustment (Davis, Morris, \& Kraus, 1998; Safdar, Struthers, \& van Oudenhoven, 2009), in particular social networks which include members of the receiving society (Jasinskaja-Lahti, Liebkind, Jaakkola, \& Reuter, 2006). Also, illustrating the importance of transnational social spaces as determinants of successful adaptation, ethnic networks abroad have been shown to increase migrant well-being (Jasinskaja-Lahti et al., 2006).

The socioeconomic position of the migrant is recognized as a key determinant of adaptation as well. "Segmented assimilation”, for example, refers to outcomes where migrants are assimilated into different segments of society as a function of social class (Portes \& Rumbaut, 2006). The analysis of second- and higher-generation immigrants shows specific generational paths of incorporation in receiving societies (Levitt \& Waters, 2002). For low status migrants this process may lead to "downward assimilation” whereby young migrants join the most disadvantaged minorities at the bottom of society (Portes \& Rumbaut, 2006), an outcome squarely at odds with early assimilationist views of upward mobility and integration in mainstream society. Migrants in low social positions have also been shown to experience greater acculturative stress and to be prone to unsuccessful adjustment (Jasinskaja et al., 2006; Polek, van Oudenhoven, \& Ten Berge, 2008).

Critical voices have argued that the distinctly psychological perspective of acculturation research may lead to underestimates of the importance of political connotations of acculturation strategies. In a discursive analysis of acculturation strategies, Bowskill, Lyons and Coyle (2007) question the seemingly self-evident superiority of the integration 
strategy. They argue that in the British media integration is often confounded with assimilation and presented as the optimal response to diversity. In media accounts of immigration, separation in turn was positioned as transgressive, thereby delegitimizing possible avenues of collective contestation that require strong identification with migrant groups. Similarly, it is problematic to establish whether or not migrants identify with both groups in an absolute sense, as implied by the definition of the integration orientation. For Verkuyten (2006, p.158), it is rather the degree to which they do so that is important. A related challenge for future acculturation research consists in addressing the psychological implications of the contemporary backlash against multiculturalism.

\section{Intergroup Approaches to Acculturation and Multiculturalism}

In the wake of the intergroup perspective developed by the Interactive acculturation model (Bourhis et al., 1997), recent research has examined the effects of match and mismatch between acculturation orientations held by migrant groups and receiving societies (van Oudenhoven, Ward, \& Masgoret, 2006; Roccas et al., 2000; Zagefka \& Brown, 2002). Minority and majority attitudes towards acculturation can either be concordant and give rise to consensual relations between majorities and minorities (especially when both groups agree on integration or assimilation as preferred modes of acculturation), or discordant, evidenced by a mismatch between minority preferences and majority expectations, leading to problematic or even conflictual relationships (Bourhis et al., 1997). The relational outcomes of a mismatch of intergroup definitions of acculturation orientations include, for migrants, heightened acculturative stress, and, for members of the receiving society, stereotyping and discriminatory behaviors, for example in educational or health care institutions, at the workplace, in housing decisions or in encounters with the police. 
Such mismatch was evidenced in the Netherlands where Moroccan and Turkish immigrants have been shown to prefer integration, while Dutch nationals believed that separation, their least liked orientation, was mainly chosen by these migrant groups (van Oudenhoven et al., 1998). In Germany, research has similarly shown that whereas migrant groups preferred strategies implying contact with the receiving society, majorities thought they endorsed strategies implying culture maintenance (Zagefka \& Brown, 2002). More importantly, this study revealed that greater perceived mismatch between migrant and majority acculturation orientations at the individual level deteriorated the perceived quality of intergroup relations (in terms of ingroup favoritism and perceived discrimination) for both minorities and majorities. Other research has demonstrated that the expectations of the German majority with respect to migrants’ modes of acculturation predicted their own attitudes and behavior towards migrants: majority respondents who valued culture maintenance by migrants expressed lower prejudice and less discrimination towards them, with cross-lagged longitudinal analyses showing that the direction of causality between acculturation expectations and discriminatory conduct could go both ways (Geschke, Mummendey, Kessler, \& Funke, 2010; see also Zick, Wagner, Van Dick, \& Petzel, 2001).

The intergroup nature of migrant incorporation in receiving societies is also evidenced at the level of public attitudes towards multiculturalism and the policies destined to implement its principles (see Verkuyten, 2006). A common finding is that support for multicultural policies is higher among migrant groups than among national majorities (van Oudenhoven et al., 1998; Verkuyten, 2005b). These results imply that in an asymmetrical intergroup context, minorities tend to favor collective forms of social justice which protect their rights against a numerically superior majority. This pattern of greater support by minorities for collective (rather than individual) forms of justice has been experimentally demonstrated in early work on minority rights in South Africa by Azzi (1992), suggesting that 
minority support for multiculturalism is not a mere product of intergroup competition, but rather the outcome of procedural justice concerns in minority-majority settings. In another study on support for minority rights with Turkish and Kurdish participants in the Netherlands, Verkuyten and Yildiz (2006) experimentally induced either a Dutch or a Turkish context for minority rights. They did not find any difference between the two migrant groups in their support for minority rights in the Dutch context where both groups were minorities. In the Turkish context, however, Kurdish participants showed greater support for minority rights than Turkish participants who represent the majority group in this context.

Support for multiculturalism has also been examined as a function of perceived essentialism of migrant groups. Verkuyten and Brug (2004) showed that greater perceived essentialism of migrant groups reduced the support for multiculturalism among majority groups, while the opposite was true for minority groups: The more they perceived migrant groups as authentic and permanently different from majority groups, the more they supported multiculturalism. The perception of essentialized migrant groups is thus threatening for majority groups, while it backs claims for recognition and social change among minority groups. A similar pattern of results was evidenced in a study on ingroup identification, showing that the more migrants identified with their group, the more they supported multiculturalism, while higher ingroup identification by majority members led to opposition to multiculturalism (Verkuyten \& Brug, 2004; Verkuyten, 2005b). These findings suggest that ingroup identification by minority groups is associated with identity affirmation and the support of group-differentiated policies. Ingroup identification with majority groups, in turn, highlights the threatening aspects of multiculturalism. This pattern of findings has become known as the "multiculturalism” hypothesis (Verkuyten, 2005b), and has also received experimental support in studies where multicultural vs. colorblind ideologies have been 
manipulated (Wolsko, Park, \& Judd, 2006; for a general review of cognitive effects of multiculturalism, see Crisp \& Turner, 2011).

\section{MAJORITY ATTITUDES TOWARDS IMMIGRATION: THREAT PERSPECTIVES}

References to threat are omnipresent in anti-immigrant rhetoric disseminated in the public sphere: Immigrants are depicted as "flooding” the country, "taking” away the jobs of citizens, abusing the welfare system and undermining national values (e.g., Every \& Augoustinos, 2007). In many European countries, for example, following the joining of former Eastern European countries in the European Union, the "Polish plumber" has gained some notoriety as an objectification of an immigrant taking away jobs from national plumbers. Such allegations imply that the arrival and presence of immigrants yields various negative consequences for citizens of receiving countries. The virulent French debate about wearing headscarves is an example of supposed threat to national values disseminated in public discourse. Moreover, globally covered events in the 2000’s involving Islamist perpetrators, including terrorist attacks in New York, Madrid and London, the murder of Dutch film maker Theo Van Gogh in Amsterdam, or the violent reactions to the Prophet Mohammed cartoons in Denmark, have fuelled threat perceptions regarding Muslim immigrants in particular. The alleged threats are subsequently used as arguments to oppose rights of immigrants and restrict their entry into receiving societies. In this section, we present research that examines the role of threat in explaining the psychological processes underlying attitudes towards immigrants by members of receiving societies.

The notion of threat is present in a plethora of social psychological theories that are concerned with understanding the underpinnings of anti-immigration attitudes (see Riek, Mania, \& Gaertner, 2006). Threat is an umbrella term with multiple meanings. Broadly defined, threat appraisals refer to the anticipation of negative consequences related to the 
arrival and presence of immigrants in a receiving society. Threat research generally differentiates two main routes through which threat relates to anti-immigration attitudes: material or realistic threats on the one hand, and value or symbolic threats on the other (e.g., Riek et al., 2006; Sears \& Funk, 1991; Stephan \& Renfro, 2003). Material threats anticipate negative consequences with respect to the distribution of valued and usually scarce tangible resources in the receiving society, including economic assets, political power and physical well-being of national ingroup members. Value-based threats, in turn, foresee perceived nontangible negative consequences of immigrant presence and are derived from the assimilationist idea that all members of the national ingroup should share the same values and conform to common norms. Threat has also been assessed with intergroup anxiety, involving feelings of uneasiness and awkwardness related to intergroup interactions (Stephan \& Stephan, 1985). The psychological nature of threat thus varies, since threat may refer to the perceived likelihood of negative immigration consequences or to an emotional anticipation involving fear and anxiety (Esses, Jackson, \& Armstrong, 1998).

Negative outcomes of immigrant presence can furthermore be anticipated on the individual or the collective level, reflecting motivations of individual or collective selfinterest (e.g., Burns \& Gimpel, 2000; Citrin, Green, Muste, \& Wong, 1997; Jackson, Brown, Brown, \& Marks, 2001; Stephan \& Renfro, 2003). Individual threat perceptions describe situations where members of the receiving society are concerned that their individual interests are menaced by immigration. Collective threat perceptions refer to conditions where the ingroup as a whole — be it national, ethnic or regional —is seen as threatened by immigration.

A potentially confusing issue is that the use and theoretical status of threat as an explanatory variable in immigration attitude research varies widely. Threat has been conceived as a component of prejudice and as an antecedent, mediator or moderator of the psychological processes underlying anti-immigration stances. Moreover, given the 
widespread presence of threat rhetoric in the public sphere, perceived threat may also be seen as the expression of endorsement or rejection of threat-based political arguments. Yet, despite their differences in the underlying assumptions and the forms of threats they investigate, the various theories converge in viewing threat as closely related to anti-immigration attitudes.

Threat rhetoric often targets generic immigrants as sources of potential danger to society. However, the way perceived threat affects intergroup attitudes also depends on the specific immigrant group under consideration. “Culturally distant” and stigmatised immigrant groups whose members may wear visible signs of cultural or religious affiliation, or differ in physical appearance, are the most likely targets of value-based threat rhetoric. This is the case for example for low-skilled Hispanic laborers in the U.S. or Muslim immigrants in Europe. Accordingly, immigrants deemed to be “culturally similar” and often originating from wealthier countries are less likely targets of value-based threat rhetoric. These "similar" immigrants may however evoke material threat, in particular related to the job market.

In this section we first overview different lines of research investigating material threat and then move on to models of value-based threats. Lastly, we examine how national identification and intergroup contact affect threat perceptions.

\section{Material Threats and Immigration Attitudes}

Different theoretical models focus on locating the causes of anti-immigrant attitudes in the competitive intergroup structure between the national ingroup and immigrant outgroups. Based on Realistic conflict theory (Sherif, 1967), these models assume that competition over scarce resources between social groups leads to intergroup conflict and, consequently, to negative attitudes towards immigrant outgroups. As a result, individuals who perceive to be in competition with an immigrant outgroup are most likely to experience material threat and develop negative attitudes towards members of the group. Group position theory (Blumer 
1958; Bobo 1999) and Social dominance theory (Sidanius \& Pratto, 1999) take a similar approach, underscoring that societies are structured as group-based hierarchies which oppose dominant (national majority) to subordinate (immigrant minority) groups (see also Esses, Jackson, Dovidio, \& Hodson, 2005). Dominant national ingroups propagate “legitimizing myths" that portray the majority-immigrant relationship as competitive in order to justify their higher status, resources, and power.

Perceived economic threat has been shown to relate to discriminatory attitudes towards immigrants in Europe (McLaren, 2003; Pereira, Vala, Costa-Lopes, 2010) and North America (e.g., Citrin et al.,1997; Esses et al., 1998). The differential impact of threat rhetoric as a function of the targeted immigrant group is illustrated in an experimental study by Brader, Valentino, and Suhay (2008) showing that when news reports on Latino immigrants emphasized the costs of immigration (i.e., material threat) instead of its benefits, White U.S. citizens supported reduction of immigration, preferred English-only laws, and requested information from anti-immigration groups. This was far less the case when European immigrants were featured in the reports. In another study, fictitious editorials depicting a highly skilled immigrant group (rather than a vaguely described immigrant group) arriving in a context where jobs are scarce evoked perceptions of competition and resulted in generalized negative attitudes towards immigrants in Canada (Esses et al., 1998).

Perceived material threat does not necessarily affect attitudes directly but may involve mediation and moderation processes. In an Australian study, the relationship between perceived material threat and exclusionary attitudes towards asylum seekers was mediated by procedural and distributive justice perceptions (Louis, Duck, Terry, Schuller, \& Lalonde, 2007). The results of a Canadian study, in turn, showed that competitive zero-sum beliefs ("the more for immigrants, the less for us") mediated the relationship between social dominance orientation (SDO) and attitudes towards immigrants (Esses et al., 1998). 
Individuals high on SDO were more likely to report that gains by immigrants would result in losses for the receiving society, a view that in turn was positively related to anti-immigration stances. In an attempt to understand why immigrants remained a target of prejudice in Switzerland despite prevailing anti-discrimination norms, Falomir-Pichastor, Munoz-Rojas, Invernizzi, \& Mugny (2004) showed that economic threat moderated the impact of antidiscrimination norms on discrimination. Experimentally induced anti-discrimination norms reduced discrimination of immigrants only when threat was low (i.e., when fictitious research findings demonstrated that a high proportion of immigrants did not increase unemployment).

Low-status positions of majority members, assessed with low education and income levels, have been associated with perceived material threat. As immigrants often occupy lowstatus positions, low rather than high-status majority members are more likely to be confronted with immigrants. They are therefore also more likely to view themselves in competition for similar resources such as affordable housing and jobs. Indeed, the relationship between low social position and negative immigration and cultural diversity attitudes has often been demonstrated (e.g., Hainmueller \& Hiscox, 2007; Scheepers, Gijsberts, \& Coenders, 2002; for an overview Ceobanu \& Escandell, 2010). Similarly, low status ethnic minorities such as Blacks and Hispanics in the U.S. are more likely to view themselves in competition with immigrants and thus to be more opposed to immigration (e.g., Burns \& Gimpel, 2000). However, competition is not the sole explanation for the links between status, threat perceptions and anti-immigrant prejudice. Alternative explanations of status differences in the expression of anti-immigration prejudice highlight high status groups' greater awareness of anti-discrimination norms and more subtle expressions of prejudice (e.g., Jackman \& Muha, 1984; Hainmueller \& Hiscox, 2007). The symbolic politics approach (e.g., Sears \& Funk, 1991) provides yet another explanation by suggesting that the effects of social 
status are due to differential political socialization of groups, that is, differential socialization experiences rather than status per se is suggested to underlie negative immigration attitudes.

With respect to collective self-interest, Citrin, Sears, Muste, and Wong (2001) have shown that although personal economic circumstances played little role in support for reducing immigration, pessimism about the national economy and beliefs about the negative consequences of immigration on jobs and taxes predicted anti-immigration attitudes (see also Burns \& Gimpel, 2000; Stephan \& Renfro, 2003). Somewhat paradoxically, while people who see their national ingroup as relatively disadvantaged in comparison with immigrant outgroups have been shown to display stronger anti-immigrant attitudes (e.g., Pettigrew, Christ, Wagner, Meertens, van Dick, \& Zick, 2008), this was also the case for those who see their ingroup as relatively advantaged in relation to immigrant outgroups (Guimond \& Dambrun, 2001). In this latter case, immigrant prejudice is interpreted as a strategy to maintain the privileges of the high-status ingroup.

\section{Threatening the Values of the National Ingroup}

In current day Western societies, the worldviews of Muslim immigrants are frequently considered to pose a threat to national values. The November 2009 referendum in Switzerland where $57.5 \%$ of the voting population supported a minaret construction ban illustrates the political consequences of such perceptions of value threat. Perceived value threat originates in presumed differences in belief systems, worldviews, and morality between immigrant outgroups and national majorities (e.g., Sears \& Funk, 1991). Purportedly incompatible values of immigrant communities are portrayed as a menace to a homogeneous and unified conception of the national ingroup based on endorsement of common values (Biernat \& Vescio, 2005; Esses, Dovidio, Semenya, \& Jackson, 2005). Different lines of value threat 
research converge in the argument that values and norms of the national majority are used as the sole frame of reference for judging immigrant outgroups (see Joffe \& Staerklé, 2007).

Importantly, negative immigration attitudes are triggered by perceptions or beliefs in profound value differences rather than by any objective difference, Huntington (2004), for example, argued that the continuing immigration from Latin America threatens the linguistic and Anglo-Protestant cultural identity of the U.S.. Based on both census and survey data, this view was challenged by Citrin, Lerman, Murakami, and Pearson (2007) by showing that by the third generation, most Hispanic immigrants identify as Americans and are monolingual in English, and that therefore alleged value differences no longer exist.

The origins of immigration attitude research on value threat can be found in theories initially developed to understand the continuing racism against Blacks in the U.S.. This research has demonstrated that old-fashioned bigotry has been replaced with a more hidden type of prejudice that is socially more acceptable because it is anchored in the purported lack of conformity with key national values (see Sears \& Henry, 2005; Gaertner \& Dovidio, 2004; McConahay, 1986). In symbolic racism theory, for example, Blacks are perceived to violate, more than Whites, traditional American values such as self-reliance, the work ethic, and respect for authority (Sears \& Henry, 2005). In an influential paper, Pettigrew and Meertens (1995) conceptualized similar ideas in the European context, leading them to distinguish between blatant and subtle forms of prejudice against immigrants. Perceived value violation by immigrants is a central component of subtle prejudice against immigrants, in addition to exaggeration of cultural differences and the denial of positive emotions towards immigrants. Both symbolic racism and subtle prejudice have been shown to underlie support for various restrictive policies such as expulsion of value-violating immigrants in Europe (Pettigrew \& Meertens, 1995) and Whites’ opposition to immigration and multilingualism in the U.S. (Sears, Citrin, Cheleden, \& van Laar, 1999; see also Huddy \& Sears, 1995). Drawing 
on this seminal work, value-based threats have regularly been shown to be associated with anti-immigrant prejudice (McLaren, 2003; Sides \& Citrin, 2007). For example, a study conducted in the Netherlands showed that perceived symbolic, but not material, threat predicted prejudice against Muslim immigrants (Velasco Gonzáles, Verkuyten, Weesie, \& Poppe, 2008). Another study showed that perceived collective cultural threats were the most important types of threat underlying prejudice towards Turks, Moroccans, Surinamese and refugees in the Netherlands (Sniderman, Hagendoorn, \& Prior, 2004).

Although value and material threat are sometimes conceived as rival explanations of anti-immigrant attitudes, some research suggests on the contrary that they are complementary, providing different, but not mutually exclusive, motivational explanations of immigration attitudes (e.g., Huddy \& Sears, 1995; Riek et al., 2006; Sniderman et al., 2004). A case can be made that perceptions of material and value-based threat relate to the fundamental processes of dealing with intergroup similarity and difference, respectively. Material threat implies that similarity with immigrants is threatening since "they" are motivated to acquire the same resources "we” want, too. Value threat, in turn, implies that difference with immigrants is threatening, since "they" are too different to be integrated in our society. This hypothesis is supported by a study that revealed more negative attitudes towards Mexican immigrants in the U.S. when participants focused either on intergroup difference on positive interpersonal traits such as 'generous' and 'friendly' (supporting value threat predictions) or on intergroup similarity on work-related traits such as 'competent' and 'hardworking' (supporting material threat predictions)(Zárate, Garcia, Garza, \& Hitlan, 2004).

Notwithstanding pressing calls for assimilation and the elimination of intergroup differences, the blurring of boundaries between the national ingroup and immigrant outgroups may also lead to perceived threat and thus fuel anti-immigrant attitudes (for distinctiveness threat e.g., Jetten, Spears, \& Postmes, 2004; for threat to the hierarchical status quo, Sidanius 
\& Pratto, 1999). Ideological orientations have been shown to account for some of these different effects of threat by shaping the experience of threat which subsequently drives antiimmigration stances (Cohrs \& Stelzl, 2010; Duckitt, 2006; Guimond, Dambrun, Michinov, \& Duarte, 2003; see Feldman, Chapter 20). Recent research in the U.S. and Switzerland demonstrated that when immigrants were portrayed as adapting to the values of the receiving society (i.e., becoming similar to the national majority), anti-egalitarian (high SDO) nationals motivated to enforce status boundaries were more willing than low SDO nationals to persecute immigrants than when they did not make such integrative efforts (Thomsen, Green, \& Sidanius, 2008). In contrast, right-wing authoritarian (RWA) nationals concerned by conformity with ingroup norms were more willing than nationals low on RWA to persecute immigrants when they did not make integrative efforts.

\section{National Identification and Threat}

Because immigrants are perceived and constructed as threatening historically developed national values, national identification plays an important role in anti-immigrant attitudes. Research has shown that ethnic majorities within countries are more likely to see themselves as legitimate representatives of the nation and are therefore more likely to identify with the nation (Devos \& Banaji, 2005; Staerklé, Sidanius, Green \& Molina, 2010). This ingroup identification makes members sensitive to things that may harm the group; therefore, individuals who identify strongly with their country are likely to be more concerned by the national interest than less identified individuals. Accordingly, national identification has been shown to be an antecedent of more intense feelings of threat (e.g., Riek et al., 2006). Threat triggers a motivation to defend the identity of the nation that may lead more strongly identified individuals to hold more negative attitudes towards immigrants (e.g., Blank \& Schmidt, 2003; Esses, Dovidio et al., 2005; Mummendey, Klink, \& Brown, 2001). Examining 
the attitudes of Dutch adolescents, Velasco Gonzáles et al. (2008) showed that national identification increased anti-Muslim prejudice, but this relationship was fully mediated by perceived symbolic threat. National identification may also influence the way individuals react to threat, by strengthening the link between perceived threats and hostile attitudes towards immigrants (Stephan \& Renfro, 2003). The relationship between perceived realistic threat and prejudice towards Russian immigrants in Israel has for example been shown to be stronger for high national identifiers (Bizman \& Yinon, 2001).

However, not only the degree of national attachment determines whether antiimmigration attitudes are increased, but also its form and content. While an uncritical and idealizing attachment to the nation based on a sense of national superiority is positively related to anti-immigration attitudes, the relationship may be negative when attachment implies pride in the nation and excludes intergroup comparisons (Blank \& Schmidt, 2003; Green, Sarrasin, Fasel, \& Staerklé, in press; Mummendey et al., 2001). Thus it is not identification per se that drives anti-immigration stances, but rather the meaning that individuals and groups attribute to identity (Reicher \& Hopkins, 2001). Research has for example shown that national identification was related to prejudice towards asylum seekers in England only to the extent that people endorsed an ethnic conception of the nation, that is based on ancestry and blood ties (Pehrson, Brown, \& Zagefka, 2009; see also Meeus, Duriez, Vanbeselaere, \& Boen, 2010). In a study highlighting the importance of representations of national history, the experimentally emphasized Christian roots of Dutch nationhood led low national identifiers to oppose rights of Muslim immigrants to the same extent as did high identifiers (Smeekes, Verkuyten, \& Poppe, 2011). Yet, under specific circumstances, national identification has also been shown to improve attitudes towards immigrants. Esses, Dovidio et al. (2005) demonstrated that immigration attitudes, especially of individuals endorsing high 
levels of SDO became less negative when a common national identity and common roots of the national majority and immigrants were experimentally made salient.

\section{Perceived Threat and Intergroup Contact}

Finally, reduction of threat plays an important role in explaining how intergroup contact decreases prejudice (see Hewstone \& Al-Ramiah, Chapter 29). The classic intergroup contact hypothesis states that positive interaction (i.e., contact) between members of different groups (e.g., through intergroup friendships, Pettigrew, 1997 or transnational social relations, Mau, Mewes, \& Zimmermann, 2008) improves intergroup relations, especially when such interaction occurs under favorable conditions (e.g., equal status between groups, common goals, institutional support, Allport 1954). There is a now a considerable body of research on mediating processes showing that contact improves attitudes towards immigrants via reduced intergroup anxiety which represents a form of perceived threat (Pettigrew \& Tropp, 2008, in addition to threat reduction, their meta-analysis identified empathy and knowledge of the immigrant outgroup as mediators; see Binder et al., 2009, for longitudinal evidence of threat reduction as a mediator). A study in Italy showed that intergroup anxiety decreased with increasing contact which then reduced prejudice toward African immigrants (Voci \& Hewstone, 2003). In another study, cross-group friendships between White high school pupils and South Asian pupils in England predicted more positive attitudes toward South Asians by the English pupils (Turner, Hewstone, \& Voci, 2007). This relationship was mediated by lower intergroup anxiety and increased self-disclosure (i.e., voluntary presentation of information of a personal nature) among English pupils. The same pattern was also found for extended contact (i.e., knowing ingroup members who have immigrant friends). Yet another English study showed that the negative effect of direct and extended contact with Muslims on 
anti-Muslim attitudes was mediated by lower intergroup anxiety (Hutchinson \& Rosenthal, 2011).

Although the contact research tradition has advanced our understanding of the mechanisms underlying the reduction of anti-immigrant prejudice, Dixon, Durrheim, and Tredoux (2005) call for research that goes beyond examining the reduction of individual prejudice as the sole possible outcome of contact. While ideal forms of contact (i.e., positive, frequent, among equals and institutionally sanctioned) indeed reduce threat perceptions, the more common mundane and superficial contacts, or negative contacts, may consolidate or even enhance threat perceptions and intergroup anxiety. Moreover, intergroup contact has been shown to lead to potentially unfavorable outcomes for immigrants at the collective level, since personal contacts across group boundaries may deflect attention from structural inequality between disadvantaged and privileged ethnic groups. As a result, harmonious intergroup contact may paradoxically decrease support for political measures addressing these inequalities (Saguy, Tausch, Dovidio, \& Pratto, 2009; Wright \& Lubensky, 2009). Contact research should therefore go beyond the analysis of the impact of contact at the individual level, and include analyses that demonstrate how contact patterns relate to political outcomes such as institutional discrimination and immigration policies and more broadly to social change.

\section{A Cautionary Note}

To conclude, some words of caution regarding common pitfalls in threat research are in order. First, the use of threat measures to predict immigration policy attitudes has been criticized as tautological. If there is content overlap in measures of threat and prejudice, then threat may simply be a variant of prejudice (e.g., Sniderman et al., 2004). 
Second, socio-demographic factors such as income and education level are rather distal indicators of material threat and do therefore not warrant firm conclusions as to the psychological processes underlying the relationship between material threat and prejudice (Sears \& Funk, 1991).

Third, the variety of methods used to study the role of threat in anti-immigration attitudes makes it difficult to establish an equivocal causal order between threat and prejudice. In survey research, threat perceptions are usually assessed by explicitly asking respondents the extent to which they feel immigrants threaten values or job opportunities of the national majority. Threat measures are then used to predict prejudiced policy stances. Such crosssectional survey research cannot exclude reverse causality. Experimental research, in turn, addresses these critiques by manipulating threat perceptions in various ways (see also Schlueter, Schmidt, \& Wagner, 2008, for longitudinal evidence). Many studies use fictitious newspaper articles, editorials, research findings or policy framings to manipulate threat perceptions, thereby simulating dissemination of threat-based arguments in the media and the public sphere (e.g., Esses et al., 1998; Falomir-Pichastor et al., 2004; Pratto \& Lemieux, 2001). However, controlled experiments remain artificial situations_-frequently using student populations - and thus cannot conclusively show the conditions under which threat shapes immigration policy stances among the general population in the real world. Similarly, experiments studying the impact of contact on intergroup attitudes are limited due to difficulties in simulating long-term cumulative contact, across different situations and with different outgroup members (for a discussion of methodological issues in intergroup contact research, see Christ \& Wagner, in press).

Thus, any one method alone does not permit unequivocal causal interpretation of the threat-prejudice nexus. Confidence in causal conclusions can only be increased by careful consideration of findings of theory-driven research using several methods on the one hand, 
and by specifying how specific immigration contexts affect threat-based psychological processes on the other.

\section{CONTEXTUAL ANALYSES OF IMMIGRATION ATTITUDES}

How do macro-level factors shape individual immigration attitudes and to what extent do these processes vary over time and across territorial or institutional contexts? In this fourth part of the chapter, we overview how political psychology can benefit from examining the impact of contextual (e.g., national, regional) factors on attitudes related to immigration and multiculturalism. The development of high quality international social surveys, such as the European Social Survey (ESS) and the International Social Survey Programme (ISSP) has fostered cross-national and cross-regional research that takes into account the impact of contextual factors on individual-level processes and outcomes. The basic rationale for such investigations is that individuals' attitudes towards immigration and multiculturalism are shaped by the social and political contexts in which they develop, over and above the individual-level determinants of political attitudes. In recent years, the necessary multi-level research designs have become common as they can now be readily implemented with a number of software packages. Multilevel approaches allow the simultaneous examination of different levels of analysis by combining individual-level predictors with national- or regional-level factors in a single explanatory model (e.g., Hox, 2010). Thus, psychological explanations of public opinion towards immigration and immigrants can be complemented with political, historical, and institutional explanations.

The conceptualization of regional and national contexts has up to now mainly relied on competition and threat theories as well as on intergroup contact theory (Ceobanu \& Escandell, 2010). The two most studied context-level characteristics relate to national economic conditions (e.g., GDP, unemployment rate) and immigration and diversity patterns 
(e.g., proportion of immigrants, change in immigrant proportion, ethnic fractionalization). A more recent research trend has examined the impact of the ideological context in which immigration attitudes emerge. In the following, we overview and discuss these different strands of research.

\section{Extending Threat and Contact Approaches to a Contextual Level}

Drawing on both realistic conflict theory and social identity theory, Scheepers et al. (2002) were among the first to theorize threat as a context-level factor in a multi-level perspective, formalized in ethnic competition theory (see also Quillian, 1995). On the individual level, ethnic competition theory defines competition in terms of the social conditions (e.g., professional category, income) of members of the receiving society. Lowstatus conditions elicit perceptions of a competitive relationship with immigrants that in turn give rise to anti-immigration stances. Competition on the contextual level, in turn, is assessed with macro-social, economic conditions of a country or a region, assumed to affect the competitiveness between members of the receiving society and immigrants. In a disadvantaged economic context, indexed by high unemployment rates for example, competition for scarce resources such as jobs is likely to be greater than in an advantaged economic context. In line with this reasoning, Quillian (1995) showed across twelve European countries that poor economic conditions in a country increased immigrant prejudice over and above individual-level predictors (see also Green, 2009; Kunovich, 2004).

With respect to country-level immigration patterns, the threat approach suggests that a high or increasing proportion of immigrants can elicit both perceived material and value threat. A high number of immigrants may be seen as deteriorating the economic opportunities of receiving country members by increasing competition (material threat), but it may also be seen as challenging the national culture, its values and lifestyle (value threat). In a study 
comparing 15 European countries, Scheepers et al. (2002) showed that individuals living in similar conditions as immigrants were more likely to endorse threat perceptions, and that a high proportion of non-EU citizens within a country was directly related to ethnic exclusionism, assessed with opposition to the granting of civil and social rights to immigrants. Comparing measures of immigrant presence, another study showed that while the percentage of low-status immigrants in European countries did not affect individual threat perceptions, a higher percentage of non-Western immigrants was associated with higher country average levels of perceived threat related to immigration (Schneider, 2008). Contextual characteristics can also have interactive effects as already demonstrated by Quillian (1995) who showed that while the proportion of immigrants from non-European countries increased racial prejudice, this relationship was more likely to occur in countries with poor economic conditions.

In addition to territorial contexts, the threat approach has been applied for examining the impact of temporal contexts. Changes in immigration and economic conditions as well as the way they are covered in the media affect perceived competition. Pooling Dutch surveys over 1979-2002, Coenders, Lubbers, Scheepers, and Verkuyten (2008, study 1) showed that in times of high levels of immigration and increased unemployment, ethnic discrimination was more widespread (see also Semyonov, Raijman, \& Gorodzeisky, 2006). Moreover, birth cohorts having experienced high immigration and unemployment in their formative pre-adult years also expressed greater ethnic discrimination (see Sears \& Brown, Chapter 1 for political socialization). Similar patterns were found across European countries in an examination of a narrower time frame from 2002 to 2007 (Meuleman, Davidov, \& Billiet, 2009). This study showed that countries with weaker inflows of immigrants had more tolerant immigration attitudes than those with high levels of immigration, and that attitudes toward immigration became more tolerant particularly in countries where unemployment rates did not increase. 
Yet, although predictions based on a threat approach have received much empirical support, research has also produced mixed findings (e.g., Hjerm 2007; Sides \& Citrin, 2007; Strabac \& Listhaug, 2008). In a comparison of 20 European countries, Sides and Citrin (2007) found for example no effects of the economic situation and of the proportion of immigrant populations on hostile attitudes towards immigration. Strabac and Listhaug (2008), in turn, found no effect of the proportion of Muslim populations on anti-Muslim attitudes across European countries. However, the European Value Survey data used in their study was collected prior to the terrorist attacks during the last decade that fuelled negative attitudes towards Muslims which may explain the absence of the effects. Moreover, comparing attitudes towards foreigners in different regions of Germany, Semyonov, Raijman, Yom Tov, and Schmidt (2004) found that the actual proportion of the immigrant population in a region did not have effects on such attitudes, whereas a high perceived size of the foreign population in the region was associated with perceived threat and discriminatory attitudes towards foreigners.

The processes underlying the impact of the proportion of immigrants in a country on its public opinion remain debated. Predictions derived in recent extensions of intergroup contact theory are indeed at odds with those derived from a threat theory perspective: Contact theorists have established that living in culturally diverse societal contexts, that is, with a high proportion of immigrants, provides more contact opportunities, notably through intergroup friendships which decreases rather than increases perceived threat and antagonistic attitudes towards immigration and cultural diversity (Wagner, Christ, Pettigrew, Stellmacher, \& Wolf, 2006; see also J.C Dixon, 2006, for Whites’ attitudes towards ethnic minorities in the US). Support for these contentions has been found especially in studies comparing within-country regions. The proportion of immigrants within German districts, for example, was negatively related to immigrant prejudice and this relationship was mediated by contact at the workplace 
and in neighborhoods (Wagner et al., 2006). These findings suggest that opportunities for contact explain a part of the relationship between ethnic composition of a community and the level of immigrant prejudice of its members.

Although the contact and threat effects concerning the proportion of immigrants may contradict each other, their opposing effects can nevertheless occur simultaneously. Schlueter and Wagner (2008) demonstrated that the regional proportion of immigrant populations in Europe increased both intergroup contact and perceived threat. Pettigrew, Wagner, and Christ (2010) showed that the effect of contact is based on direct experience with immigrants and thus affected by the actual size of immigrant populations within German regions, whereas perceived threat is triggered by the perception of immigrant presence. Other studies have shown that the interplay between threat perceptions and intergroup contact affects and is affected by context-level factors. For example, examining 17 European countries, McLaren (2003) revealed that while the percentage of foreigners in a country increases perceived threat, having immigrant friends buffers this effect. Thus, individuals with immigrant friends living in highly diverse contexts will feel less threatened by diversity than those without such friendships. Similarly, the percentage of foreign-born in U.S. regions had less impact on Whites’ immigration attitudes when their interpersonal networks included non-White members (Berg, 2009). Moreover, although positive intergroup contact is negatively related to anti-immigrant stances, this beneficial effect of contact may be more pronounced in diverse contexts where intercultural encounters are commonplace. In line with this idea, the proportion of immigrants in European countries has been shown to moderate the relationship between intergroup contact and anti-immigrant prejudice (Semyonov \& Glickman, 2009). Positive contact reduced negative attitudes towards immigrants to a greater degree in countries with a large number of non-Europeans, compared to countries with a smaller number of non-Europeans. Extended, indirect contact (knowing ingroup members who have 
immigrant friends), however, has been shown to be more effective in reducing prejudice for individuals living in segregated neighborhoods with only few direct contact experiences with immigrants, compared to individuals from mixed neighborhoods where more opportunities for direct contact exist (Christ et al., 2010).

The territorial size of the context-level unit of analysis may explain some of the seeming contradictions between the predictions derived from threat and contact approaches. The positive effects of intergroup contact have been suggested to occur at a proximal and local (e.g., municipality, neighborhood or district) level, where it is plausible that immigrants and members of the receiving society interact in their daily activities (see Wagner et al. 2006; Schmid, Tausch, Hewstone, Hughes, \& Cairns, 2008). A large presence of immigrants at a distal, national level, however, may be more likely to enhance threat perceptions due to an increased political concern with immigration, reflected in widespread anti-immigrant discourse using threat discourse in the media. In line with this argument, a U.S. study examining attitudes of Asian Americans, Blacks, Latinos and Whites found that interethnic diversity reduced perceived threat and prejudice at the neighborhood level, but increased it at the city (“metropolitan”) level (Oliver \& Wong, 2003). Similarly, a study across European countries showed that living in mixed-as opposed to homogeneous or highly ethnic— neighborhoods reduced threat perceptions and social distance towards immigrants, whereas the immigrant ratio in the country increased threat perceptions (Semyonov \& Glickman, 2009).

\section{Ideological Climate and Immigration Attitudes}

Individuals are embedded in everyday environments that provide normative and ideological reference knowledge guiding their thinking about societal phenomena such as immigration. This normative context can be seen as an "ideological climate" that is 
institutionalized in national laws and policies and reproduced in a political everyday culture made up by beliefs and values widely shared by members of a community. Ethnic and civic conceptions of national citizenship, for example, are elements of such an ideological climate that exists both at the policy level and at the level of shared values and beliefs in national populations. Across 15 European countries, Weldon (2006) showed that individuals in countries with ethnic citizenship regimes_requiring shared ethnicity and ancestry for citizenship — were less willing to grant political rights to ethnic minorities than individuals in countries with civic citizenship regimes (i.e., assimilationist and pluralistic regimes). Individuals in assimilationist regimes, in turn, were less tolerant than individuals in pluralistic regimes. Furthermore, national identification was related to intolerance only in ethnic citizenship regimes. In another study, Pehrson, Vignoles, and Brown (2009) demonstrated that in countries where the collective representation of nationhood was civic, anti-immigrant prejudice was reduced. Moreover, the relationship between national identification and antiimmigrant prejudice was weaker in these countries, suggesting that national identification defined by shared civic citizenship is related to a lesser degree to a desire to exclude immigrants. This is yet another demonstration that identity content determines whether or not identification relates to anti-immigration stances.

The relative strength of political parties also reflects the ideological climate of countries. A strong presence of right-wing parties, for example, has been shown to increase anti-foreigner sentiment across European countries, over and above individuals’ political orientation (Semyonov et al., 2006; see also Lahav, 2004). The picture is more complex, however, as specific ideological emphases in political party discourse moderate their impact on individuals' attitudes (Wilkes, Guppy, \& Farris, 2007). The presence of extremist parties promoting blatant racism (based on biological intergroup differences) did not affect public opinion as a whole, since such views have become socially unacceptable. Instead, the national 
prevalence of right-wing parties with a culturalist racist agenda (based on essential cultural differences) was shown to relate to anti-immigrant attitudes.

Finally, ideological climate has been measured by aggregating individual-level voting results. A study using Swiss national referenda at the level of municipalities provided an indicator of ideological climate based on actual voting behavior on a wide range of social issues (Sarrasin, Green, Fasel, Christ, Staerklé, \& Clémence, in press). This study evidenced stronger opposition to anti-racism laws in municipalities with conservative ideological climates, after accounting for individual-level ideological stances. Furthermore, in conservative municipalities with a low proportion of immigrants fewer intergroup contacts were reported: When the proportion of immigrants was high, conservative climate did not affect intergroup contacts. Overall research on ideological climates suggests that whether the climate is defined by institutional factors or by shared representations, it constitutes a framework of normative rules and expectations that individual citizens refer to when taking a stand on immigration.

\section{Open issues in contextual analyses}

Although contextual-level analyses in political psychology have contributed to our understanding of how national, regional and temporal contexts affect individual opinions regarding immigration, several open questions remain. First, most European studies focus on the proportion of immigrants or non-Europeans in general (for exceptions, e.g., Green, Fasel, \& Sarrasin, 2010; Hjerm, 2009; Schneider, 2008; Strabac \& Listhaug, 2008), despite the fact that immigrant groups who are targets of prejudice vary widely across countries. The arrival or presence of some immigrant groups (e.g., with Muslim origins) may elicit symbolic threat perceptions related to family or religious values, whereas other immigrant groups (e.g., German professionals coming to Switzerland) may trigger material threat perceptions due to 
competition in the job market. Thus further research should compare the multilevel impact of the presence of specific immigrant groups. Moreover, there is a growing need to understand how individuals who react with threat perceptions to higher ratios of immigrants differ from those who experience immigrant presence as an opportunity to build intergroup friendships. For example, examining in more detail the meaning individuals give to intergroup interactions is one step in this direction (Dixon et al., 2005).

Second, unravelling the processes that account for the context - individual attitude relationship remains both a methodological and a theoretical challenge. To this end, new hypotheses are called for in order to better understand this relationship, using novel conceptualizations of contexts as well as mediation and moderation patterns combining different levels of analysis.

Third, most multilevel research on immigration stances only considers the national majority perspective (see however Fleischmann, Verkuyten, \& Poppe, 2011; Staerklé et al., 2010), presumably because ethnic minorities are under- or misrepresented in national surveys (e.g., Feskens, Hox, Lensvelt-Mulders, \& Schmeets, 2006). Examining the minority perspective as well as the interplay between majority and minority perspectives is nevertheless essential for bringing the field forward. Finally, new approaches are needed to circumvent problems in multilevel research related to the small number of context-level units such as countries (Hox, 2010).

\section{CONCLUSION}

This chapter proposed an overview of research on migration and multiculturalism from the perspective of political psychology. We started our discussion with a historical framing of the two major modes of migrant incorporation, assimilation and multiculturalism. The second part presented research studying the perspective of migrant groups, showing the 
interactionist nature and the complexity of contemporary migrant identities as well as the pros and cons of various acculturation strategies employed by migrants. We also highlighted the intergroup nature of attitudes towards multiculturalism and of acculturation strategies between national majorities and ethnic migrant minorities. The third part focused on research investigating reactions by national majorities to immigration, in particular the role of various forms of perceived threat associated with migrant groups. The final section featured recent multilevel research on majority attitudes towards migration across national and regional contexts.

An important goal of the chapter was to relate the principles of assimilation and multiculturalism to the dialectic processes of intergroup similarity and differentiation, respectively. The overviewed research clearly indicates that migrant experiences, and reactions to immigration by receiving societies, express the complex and dynamic interplay of similarity and difference, at the level of motivations, perceptions and normative expectations. For migrant groups, qualified and selective similarity with the receiving society's majority is an asset for a successful migrant experience, for example through language acquisition and awareness of dominant social norms. At the same time, intergroup difference and concomitant identification with their ethnic group is likely to help many migrants to construct positive social identities rooted in the everyday experiences and practices associated with their ethnic group. Importantly, research has also emphasized that such differentiation processes do not only operate between migrant groups and receiving majorities, but also within migrant categories, in particular between early and recent migrants, between first-, second-, and third generation migrants, between migrant organizations defending contrasting visions of incorporation, and between different ethnic groups.

Yet, the demands and practical implications derived from the principle of intergroup similarity may be contradictory: majorities may expect migrants to "adapt" and respect "their 
values”, but when they do so, they may become threatening competitors for jobs and other material resources of the majority group. Intergroup difference can be equally paradoxical: migrants who are portrayed as (too) different from the majority culture allegedly threaten social cohesion and national values. At the same time, majorities may prefer that migrant groups, especially those they dislike, remain apart from them in order to safeguard an imaginary homogeneity of their ingroup. Intergroup difference is furthermore enhanced through majority practices that make integration more difficult, such as unequal treatment by authorities, lack of institutional support for integration, widespread discrimination or segregated housing. Research therefore needs to carefully spell out the specific meaning and practical implications of intergroup similarity and difference which is implied by political rhetoric and hidden in general attitudes towards immigrants. Research should also more clearly differentiate attitude formation towards contrasting types of immigrants, for example by comparing attitudes towards high- versus low-status immigrants or towards immigrants from culturally similar vs. distant countries. Currently, to maximize cross-national comparability, large international surveys mainly refer to generic immigrants in their item wording. However, additionally assessing attitudes towards immigrants of specific national origin — that may vary from country to country—would allow to paint a more accurate picture of the psychological processes involved in immigration attitude construction.

During the last two decades, migration and multiculturalism have become one of the most heavily debated issues in contemporary receiving societies, both at the level of political discourse and in everyday conversations. As illustrated in studies on migrant identity construction and ideological climates reviewed in this chapter, this societal communication is likely to affect the way citizens think about immigrants. Politicians, migrant group leaders, members of the civil society and other “identity entrepreneurs” (Reicher \& Hopkins, 2001) participate in the societal immigration debate by strategically communicating specific 
understandings of assimilation and multiculturalism. In this view, for example, "threat perceptions” are the outcome of social influence processes that deliberately portray certain migrant groups as "different” or "dangerous". These discourses participate in the construction and diffusion of positive and negative meanings of migration, thereby creating socially acceptable, and often simplified, ways of thinking and talking about immigrants and immigration. Both migrant groups and national majorities then rely on such social representations to deal with the realities and difficulties of multicultural societies (see Elcheroth, Doise, \& Reicher, 2011; Staerklé, Clémence, \& Spini, 2011). In future research, political psychology could gain from placing a stronger emphasis on the implications of this ongoing communicative process on how migrants construct their ethnic identities and how majorities ascribe characteristics on migrant groups.

Finally, the variety of methodological and theoretical approaches through which political psychology has studied phenomena of migration and multiculturalism is an important asset for making our research relevant to policy makers and practitioners (see Wills, 2010). Discursive, experimental and survey research have different stories to tell about migration and immigration. Yet, despite their often conflicting theoretical assumptions, we assume they share the normative goal of making our multicultural societies more inclusive and a better place to live for all citizens. Researchers in political psychology should therefore highlight the implications of their studies on migration and immigration policies. As we hope to have shown in this chapter, political psychology has a great deal to offer to promote the chances for successful migrant experiences as well as positive, enriching and constructive relationships between migrant groups and national majorities.

\section{Endnote}


${ }^{1}$ Throughout the chapter we use the term "receiving society" instead of "host society” in order to avoid connotations of migrants being passively "hosted" by national majorities. The term "migrant" is used when migration is analyzed from the perspective of those who move into new contexts, while the term "immigrant" is employed to describe the perspective of the receiving society into which migrants immigrate. 


\section{REFERENCES}

Alba, R. (2005). Bright vs. blurred boundaries: Second-generation assimilation and exclusion in France, Germany, and the United States. Ethnic and Racial Studies, 28, 20-49.

Alba, R. \& Nee, V. (2003). Remaking the American mainstream. Assimilation and contemporary immigration. Harvard: Harvard University Press.

Allport, G. W. (1954). The nature of prejudice. Reading, MA: Addison-Wesley.

Arends-Tóth, J. V., \& Vijver, F. J. R. v. d. (2006). Assessment of psychological acculturation: Choices in designing an instrument. The Cambridge handbook of acculturation psychology (pp. 142 - 160). Cambridge: Cambridge University Press.

Ashmore, R. D., Deaux, K., \& McLaughlin-Volpe, T. (2004). An organizing framework for collective identity: Articulation and significance of multidimensionality. Psychological Bulletin, 130, 80-114.

Azzi, A. (1992). Procedural justice and the allocation of power in intergroup relations. Personality and Social Psychology Bulletin, 18, 736-747.

Azzi, A. E., Chryssochoou, X., Klandermans, B., \& Simon, B. (Eds.). (2011). Identity and participation in culturally diverse societies: A multidisciplinary perspective. Chichester: Wiley.

Barry, B. (2001). Culture and equality. Cambridge: Polity Press.

Barth, F. (Ed.)(1969). Ethnic groups and boundaries: The social organization of cultural difference. London: Allen \& Unwin.

Chen, S.X., Benet-Martinez, V., \& Bond, M.H. (2008). Bicultural identity, bilingualism, and psychological adjustment in multicultural societies: Immigration-based and globalization-based acculturation. Journal of Personality. 76, 803-838. 
Berg, J. A. (2009). Core networks and whites’ attitudes toward immigrants and immigration policy. Public Opinion Quarterly, 73, 7-31.

Berry, J.W. (1990). Psychology of acculturation. In J.J. Berman (Ed.), Nebraska Symposium on Motivation, 1989, Vol. 37, Cross-Cultural perspectives (pp.201-234). Lincoln: University of Nebraska Press.

Berry, J. W. (2006). Stress perspectives on acculturation. In D.L. Sam \& J.W. Berry (Eds.), The Cambridge Handbook of Acculturation Psychology (pp. 43-57). Cambridge: Cambridge University Press.

Berry, J.W., \& Sabatier, C. (2010). Acculturation, discrimination, and adaptation among second generation immigrant youth in Montreal and Paris. International Journal of Intercultural Relations. 34, 191-207.

Biernat, M., \& Vescio, T. K. (2005). Values and Prejudice: Historical Conceptualizations and Current Issues. In C. S. Crandall \& M. Schaller (Eds.), The Social Psychology of Prejudice: Historical and Modern Perspectives (pp. 187-211). Lawrence, KS: Lewinian Press.

Binder, J., Zagefka, H., Brown, R., Funke, F., Kessler, T., Mummendey, A., et al. (2009). Does contact reduce prejudice or does prejudice reduce contact? A longitudinal test of the contact hypothesis among majority and minority groups in three European countries. Journal of Personality and Social Psychology, 96, 843-856.

Bizman, A., \& Yinon, Y. (2001). Intergroup and interpersonal threats as determinants of prejudice: The moderating role of in-group identification. Basic and Applied Social Psychology, 23, 191-196.

Blank, T., \& Schmidt, P. (2003). National identity in a united Germany: Nationalism or patriotism? An empirical test with representative data. Political Psychology, 24, 289312. 
Bloemraad, I., Korteweg, A., \& Yurdakul, G. (2008). Citizenship and immigration: Multiculturalism, assimilation, and challenges to the nation-state. Annual Review of Sociology, 34, 153-179.

Blumer, H. (1958). Race prejudice as a sense of group position. Pacific Sociological Review, $1,3-7$.

Bobo, L. D. (1999). Prejudice as group position: Microfoundations of a sociological approach to racism and race relations. Journal of Social Issues, 55, 445-472.

Bourhis, R. Y., Montaruli, E., El-Geledi, S., Harvey, S.-P., \& Barrette, G. (2010). Acculturation in multiple host community settings. Journal of Social Issues, 66, 780802.

Bourhis, R. Y., Barrette, G., El-Geledi, S., \& Schmidt, R. (2009). Acculturation orientations and social relations between immigrant and host community members in California. Journal of Cross-Cultural Psychology, 40, 443-467.

Bourhis, R. Y., Moïse, L. C., Perreault, S., \& Senécal, S. (1997). Towards and interactive acculturation model: A social psychological approach. International Journal of Psychology, 32, 369-383.

Bowskill, M., Lyons, E., \& Coyle, A. (2007). The rhetoric of acculturation: When integration means assimilation. British Journal of Social Psychology, 46, 793-813.

Brader, T., Valentino, N. A., \& Suhay, E. (2008). What triggers public opposition to immigration? Anxiety, group cues, and immigration threat. American Journal of Political Science, 52, 959-978.

Burns, P., \& Gimpel, J. G. (2000). Economic insecurity, prejudicial stereotypes, and public opinion on immigration policy. Political Science Quarterly, 115, 201-225. 
Brubaker, R. (2001). The return of assimilation ? Changing perspectives on immigration and its sequels in France, Germany and the United States. Ethnic and Racial Studies, 24, 531-548.

Brubaker, R., Feischmidt, M., Fox, J., \& Grancea, L. ( 2006). Nationalist politics and everyday ethnicity in a Transylvanian town. Princeton: Princeton University Press.

Cassidy, C., O'Connor, R.C., Howe, C., \& Warden, D. (2004). Perceived discrimination and psychological distress: The role of personal and ethnic self-esteem. Journal of Counseling Psychology. 51, 329-339.

Castles, S., \& Miller, M.J. (2009). The age of migration. International population movements in the modern world (4th Ed.). Hampshire, UK: Palgrave \& McMillan.

Ceobanu, A. M., \& Escandell, X. (2010). Comparative analyses of public attitudes toward immigrants and immigration using multinational survey data: A review of theories and research. Annual Review of Sociology, 36, 309-328.

Christ, O., Hewstone, M., Tausch, N., Wagner, U., Voci, A., Hughes, J., et al. (2010). Direct contact as a moderator of extended contact effects: Cross-sectional and longitudinal impact on outgroup attitudes, behavioral intentions, and attitude certainty. Personality and Social Psychology Bulletin, 36, 1662-1674.

Christ, O. \& Wagner, U. (in press).Methodological issues in the study of intergroup contact: Towards a new wave of research. In G. Hodson \& M Hewstone (eds.), Advances in Intergroup Contact. Psychology Press.

Chryssochoou, X. (2004). Cultural diversity: Its social psychology. Oxford: Blackwell.

Citrin, J., Green, D. P., Muste, C., \& Wong, C. (1997). Public opinion toward immigration reform: The role of economic motivations. The Journal of Politics, 59, 858-881.

Citrin, J., Lerman, A., Murakami, M., \& Pearson, K. (2007). Testing Huntington: Is Hispanic immigration a threat to American identity? Perspectives on Politics, 5, 31-48 
Citrin, J., Sears, D. O., Muste, C., \& Wong, C. (2001). Multiculturalism in American public opinion. British Journal of Political Science, 31, 247-275.

Coenders, M., Lubbers, M., Scheepers, P., \& Verkuyten, M. (2008). More than two decades of changing ethnic attitudes in the Netherlands. Journal of Social Issues, 64, 269-285.

Cohrs, J. C., \& Stelzl, M. (2010). How ideological attitudes predict host society members’ attitudes toward immigrants: Exploring cross-national differences. Journal of Social Issues, 66, 673-694.

Crisp, R. J., \& Turner, R. N. (2011). Cognitive adaptation to the experience of social and cultural diversity. Psychological Bulletin, 137, 242-266.

Davis, M. H., Morris, M. M., \& Kraus, L. A. (1998). Relationship-specific and global perceptions of social support: Associations with well-being and attachment. Journal of Personality and Social Psychology, 74, 468-481.

Deaux, K. (2006). To be an immigrant. New York: Russell Sage Foundation.

Devos, T., \& Banaji, M. (2005). American = White ? Journal of Personality and Social Psychology, 88, 447-466.

Dixon, J. C. (2006). The ties that bind and those that don't: Toward reconciling group threat and contact theories of prejudice. Social Forces, 84, 2179-2204.

Dixon, J., Durrheim, K., \& Tredoux, C. (2005). Beyond the optimal contact strategy: A reality check for the contact hypothesis. American Psychologist, 60, 697-711.

Duckitt, J. (2006). Differential effects of right wing authoritarianism and social dominance orientation on outgroup attitudes and their mediation by threat from and competitiveness to outgroups. Personality and Social Psychology Bulletin, 32, 684696. 
Elcheroth, G., Doise, W., \& Reicher, S., (2011). On the knowledge of politics and the politics of knowledge: How a social representations approach helps us rethink the subject of political psychology. Political Psychology, 32, 729-758.

Esses, V. M., Dovidio, J. F., Semenya, A. H., \& Jackson, L. M. (2005). Attitudes towards immigrants and immigration: The role of national and international identity. In D. Abrams, M. A. Hogg \& J. M. Marques (Eds.), The social psychology of inclusion and exclusion (pp. 317-337). New York: Psychology Press.

Esses, V. M., Jackson, L. M., \& Armstrong, T. L. (1998). Intergroup competition and attitudes toward immigrants and immigration: An instrumental model of group conflict. Journal of Social Issues, 54, 699-724.

Esses, V. M., Jackson, L. M., Dovidio, J. F., \& Hodson, G. (2005). Instrumental relations among groups: Group competition, conflict and prejudice. In J. F. Dovidio, P. Glick \& L. A. Rudman (Eds.), On the nature of prejudice: Fifty years after Allport. Oxford: Blackwell.

Every, D., \& Augoustinos, M. (2007). Constructions of racism in the Australian parliamentary debates on asylum seekers. Discourse \& Society. 18, 411-436.

Faist, T. (2009). Diversity - A new mode of incorporation? Ethnic and Racial Studies 32 (1) : 171-190.

Falomir-Pichastor, J. M., Muñoz-Rojas, D., Invernizzi, F., \& Mugny, G. (2004). Perceived ingroup threat as a factor moderating the influence of in-group norms on discrimination against foreigners. European Journal of Social Psychology, 34, 135-153.

Feldman, S. (in this handbook)

Feskens, R., Hox, J., Lensvelt-Mulders, G., \& Schmeets, H. (2006). Collecting data among ethnic minorities in an international perspective. Field Methods, 18, 284-304. 
Finch, B.K., Kolody, B., Vega, W.A. (2000) . Perceived discrimination and depression among Mexican origin adults in California. Journal of Health and Social Behavior, 41, 295313.

Fleischmann, F., Verkuyten, M., \& Poppe, E. (2011). Ethnic and republic identification in the Russian federation and Ukraine: A social dominance perspective. Journal of Ethnic and Migration Studies, 37, 23 - 41.

Dovidio, J. F., \& Gaertner, S. L. (2004). Aversive racism. In M. P. Zanna (Ed.), Advances in Experimental Social Psychology (Vol. 36, pp. 1-52). San Diego, CA: Academic Press.

Geschke, D., Mummendey, A., Kessler, T., \& Funke, F. (2010). Majority members' acculturation goals as predictors and effects of attitudes and behaviours towards migrants. British Journal of Social Psychology, 49, 489-506.

Glazer, N. (1997). We are all multiculturalists now. Cambridge, MA: Harvard University Press.

Gordon, M. (1964). Assimilation in American life: The role of race, religion and national origins. New York: Orxford University Press.

Green, E. G. T. (2009). Who can enter? A multilevel analysis on public support for immigration criteria across 20 European countries. Group Processes \& Intergroup Relations, 12, 41-60.

Green, E. G. T., Fasel, N., \& Sarrasin, O. (2010). The more the merrier ? The effects of type of diversity on immigration attitudes in Switzerland. International Journal of Conflict and Violence, 4, 177-190.

Green, E.G.T., Sarrasin, O., Fasel, N., \& Staerklé, C. (in press). Nationalism and patriotism as predictors of immigration attitudes in Switzerland: A municipality-level analysis. Swiss Political Science Review. 
Guimond, S., \& Dambrun, M. (2002). When prosperity breeds intergroup hostility: The effects of relative deprivation and relative gratification on prejudice. Personality and Social Psychology Bulletin, 28, 900-912.

Guimond, S., Dambrun, M., Michinov, N., \& Duarte, S. (2003). Does social dominance generate prejudice? Integrating individual and contextual determinants of intergroup cognitions. Journal of Personality and Social Psychology, 84, 697-721.

Hainmueller, J., \& Hiscox, M. J. (2007). Educated preferences: Explaining attitudes toward immigration in Europe. International Organization, 61, 399-442.

Hewstone \& Al-Ramiah (in this handbook )

Hjerm, M. (2007). Do numbers really count? Group threat theory revisited. Journal of Ethnic and Migration Studies, 33, 1253-1275.

Hjerm, M. (2009). Anti-immigrant attitudes and cross-municipal variation in the proportion of immigrants. Acta Sociologica, 52, 47-62.

Hopkins, N., \& Kahani-Hopkins, V. (2004). Identity construction and British Muslims' political activity: beyond rational actor theory. British Journal of Social Psychology, 43, 339-356.

Hopkins, N., \& Kahani-Hopkins, V. (2006). Minority group members' theories of intergroup contact: a case study of British Muslims' conceptualizations of 'Islamophobia' and social change. British Journal of Social Psychology, 45, 245-264.

Howarth, C. (2002). “So, you're from Brixton?” The struggle for recognition and esteem in a multicultural community. Ethnicities, 2, 237-260.

Hox, J. (2010). Multilevel analysis: Techniques and applications. New York: Routledge.

Huddy, L., \& Sears, D. O. (1995). Opposition to bilingual education: Prejudice or the defense of realistic interests Social Psychology Quarterly, 58, 133-143.

Huddy, L. (in this handbook) 
Huntington, S. (2004). The Hispanic Challenge. Foreign policy, 141, 30-45.

Hutchinson, P., \& Rosenthal, H. E. S. (2011). Prejudice against Muslims: Anxiety as a mediator between intergroup contact and attitudes, perceived group variability and behavioural intentions. Ethnic and Racial Studies, 34, 40-61.

Ignatiev, N. (1995). How the Irish became White. New York: Routledge.

Ingram, D. (2000). Group rights. Reconciling equality and difference. Lawrence, KS: University Press of Kansas.

Isin, F. I., \& Wood, P. K. (1999). Citizenship and identity. London: Sage.

Jackman, M. R., \& Muha, M. J. (1984). Education and integroup attitudes: Moral enlightenment, superficial democratic commitment, or ideological refinement? American Sociological Review , 49, 751-769.

Jackson, J. S., Brown, K. T., Brown, T. N., \& Marks, B. (2001). Contemporary immigration policy orientations among dominant-group members in western Europe. Journal of Social Issues, 57, 431-456.

Jasinskaja-Lahti, L. (2008). Long-term immigrant adaptation: Eight-year follow-up study among immigrants form Russia and Estonia living in Finland. International Journal of Psychology, 43, 6-18.

Jasinskaja-Lahti, I., Liebkind, K., Jaakkola, M., \& Reuter, A. (2006). Perceived Discrimination, Social Support Networks, and Psychological Well-being Among Three Immigrant Groups. Journal of Cross-Cultural Psychology, 37(3), 293-311.

Jetten, J., Spears, R., \& Postmes, T. (2004). Intergroup distinctiveness and differentiation: A meta-analytic integration. Journal of Personality and Social Psychology, 86, 862-879. 
Joffe, H., \& Staerklé, C. (2007).The centrality of the self-control ethos in Western aspersions regarding outgroups: A social representational analysis of common stereotype content. Culture and Psychology, 13, 395-418.

Joppke, C. (2007). Transformation of immigrant integration: civic integration and antidiscrimination in the Netherlands, France, and Germany. World Politics, 59, 243-273.

Joppke, C. (2009). Veil: Mirror of identity. Cambridge: Polity Press.

Kivisto, P. (2002). Multiculturalism in a global society. Oxford: Blackwell.

Klandermans, B., \& van Stekelenburg, J. ( in this handbook)

Koopmans, R., Statham, P., Giugni, M., \& Passy, F. (2005). Contested citizenship. Immigration and cultural diversity in Europe. Minneapolis, MN: University of Minnesota Press.

Kosic, A., Phalet, K. (2006). Ethnic categorization of immigrants: The role of prejudice, perceived acculturation strategies and group size. International Journal of Intercultural Relations, 30, 769-782.

Kunovich, R. M. (2004). Social structural position and prejudice: an exploration of crossnational differences in regression slopes. Social Science Research, 33, 20-44.

Kymlicka, W. (1995). Multicultural citizenship. Oxford: Oxford University Press.

Lamont, M., \& Molnar, V. (2002). The study of boundaries in the social sciences. Annual Review of Sociology, 28, 167-95

Lahav, G. (2004). Immigration and politics in the new Europe. Cambridge: Cambridge University Press.

Levitt, P., \& Waters, M. (Eds.)(2002). The changing face of home: The transnational lives of the second generation. New York: Russell Sage Foundation.

Licata, L., Sanchez-Mazas, M., \& Green, E. G. T. (2011). Identity, immigration, and prejudice in Europe: a recognition approach. In S. J. Schwartz, K. Luyckx, \& V. L. 
Vignoles (Eds.), Handbook of Identity Theory and Research (pp. 895-916). New York: Springer.

Liebkind, K., \& Jasinskaja-Lahti, I. (2000). The influence of experiences of discrimination on psychological stress among immigrants: A comparison of seven immigrant groups. Journal of Community and Applied Social Psychology, 10, 1-16.

Louis, W. R., Duck, J. M., Terry, D. J., Schuller, R. A., \& Lalonde, R. N. (2007). Why do citizens want to keep refugees out? Threats, fairness and hostile norms in the treatment of asylum seekers. European Journal of Social Psychology, 37(1), 53-73.

Masgoret, A.-M., \& Ward, C. (2006). Culture learning approach to acculturation. In D.L. Sam \& J.W. Berry (Eds.), The Cambridge Handbook of Acculturation Psychology (pp. 5877). Cambridge: Cambridge University Press.

McConahay, J. B. (1986). Modern racism, ambivalence, and the modern racism scale. In J. F. Dovidio \& S. L. Gaertner (Eds.), Prejudice, discrimination, and racism (pp. 91 - 125). San Diego: Academic Press.

McLaren, L. M. (2003). Anti-immigrant prejudice in Europe: Contact, threat perception, and preferences for the exclusion of migrants. Social Forces, 81, 909-936.

Meuleman, B., Davidov, E., \& Billiet, J. (2009). Changing attitudes toward immigration in Europe, 2002-2007: A dynamic group conflict theory approach. Social Science Research, 38, 352-365.

Meeus, J., Duriez, B., Vanbeselaere, N., \& Boen, F. (2010). The role of national identity representation in the relation between in-group identification and out-group derogation: Ethnic versus civic representation. British Journal of Social Psychology, 49, 305-320. 
Montreuil, A. \& Bourhis, R. Y. (2001). Host majority acculturation orientations towards 'valued' and 'devalued' immigrants. Journal of Cross-Cultural Psychology, 32, 718739.

Montreuil, A. Bourhis, R.Y., \& Vanbeselaere, N. (2004). Perceived threat and host community acculturation orientations toward immigrants: Comparing Flemings in Belgium and Francophones in Quebec. Canadian Ethnic Studies, 36, 113-135.

Mummendey, A., Klink, A., \& Brown, R. (2001). Nationalism and patriotism: National identification and out-group rejection. British Journal of Social Psychology, 40, 159171.

Nesdale, D., \& Mak, A. S. (2000). Immigrant acculturation attitudes and host country identification. Journal of Community \& Applied Social Psychology, 10(6), 483-495.

Oliver, J. E., \& Wong, J. (2003). Intergroup prejudice in multiethnic settings. American Journal of Political Science, 47, 567-582.

Park, R.E., \& Burgess, E.W. (1921). Introduction to the science of sociology. Chicago: University of Chicago Press.

Pehrson, S., Brown, R., \& Zagefka, H. (2009). When does national identification lead to antiimmigrant prejudice? Cross-sectional and longitudinal evidence for the role of essentialist ingroup definitions. British Journal of Social Psychology, 48, 61-76.

Pehrson, S., Vignoles, V. L., \& Brown, R. (2009). National identification and anti-immigrant prejudice: Individual and contextual effects of national definitions. Social Psychology Quarterly, 72, 21-48.

Pereira, C., Vala, J., \& Costa-Lopes, R. (2010). From prejudice to discrimination: The legitimizing role of perceived threat in discrimination against immigrants. European Journal of Social Psychology, 40, 1231-1250. 
.Pettigrew, T. F. (1997). Generalized intergroup contact effects on prejudice. Personality and Social Psychology Bulletin, 23, 173-185.

Pettigrew, T. F., Christ, O., Wagner, U., Meertens, R. W., Van Dick, R., \& Zick, A. (2008). Relative Deprivation and Intergroup Prejudice. Journal of Social Issues, 64(2), 385401.

Pettigrew, T. F., \& Meertens, R. W. (1995). Subtle and blatant prejudice in Western Europe. European Journal of Social Psychology, 25, 57-75

Pettigrew, T. F., \& Tropp, L. R. (2008). How does intergroup contact reduce prejudice? Metaanalytic tests of three mediators. European Journal of Social Psychology, 38, 922-934.

Pettigrew, T. F., Wagner, U., \& Christ, O. (2010). Population Ratios and Prejudice:

Modelling Both Contact and Threat Effects. Journal of Ethnic and Migration Studies, 36, $635-650$.

Philogène, G. (1999). From Black to African-American: A new social representation. Westport, Conn.: Greenwood-Praeger.

Phinney, J. S. (1990). Ethnic identity in adolescents and adults: review of research. Psychological Bulletin, 108, 499-514.

Piontkowski, U., Florack, A., Hoelker, P., \& Obdrzálek, P. (2000). Predicting acculturation attitudes of dominant and non-dominant groups. International Journal of Intercultural Relations, 24(1), 1-26.

Polek, E., van Oudenhoven, J. P., \& ten Berge, J. M. F. (2008). Attachment styles and demographic factors as predictors of sociocultural and psychological adjustment of Eastern European immigrants in the Netherlands. International Journal of Psychology, 43, 919 - 928.

Portes, A., \& Rumbaut, R.G. (2006). Immigrant America : A portrait ( $3^{\text {rd }}$ ed.). Berkeley : University of California Press. 
Pratto, F., \& Lemieux, A. F. (2001). The psychological ambiguity of immigration and its implications for promoting immigration policy. Journal of Social Issues, 57, 413-430.

Quillian, L. (1995). Prejudice as a response to perceived group threat: Population composition and anti-immigrant and racial prejudice in Europe. American Sociological Review, 60, 586-611.

Redfield, R., Linton, R., \& Herskovits, M. (1936). Memorandum on the study of acculturation. American Anthropologist 38, 149-152.

Reicher, S., \& Hopkins, N. (2001). Self and nation. London: Sage.

Riek, B. M., Mania, E. W., \& Gaertner, S. L. (2006). Intergroup threat and outgroup attitudes: A meta-analytic review. Personality and Social Psychology Review, 10, 336-353.

Roccas, S., Horenczyk, G., \& Schwartz, S. H. (2000). Acculturation discrepancies and wellbeing: the moderating role of conformity. European Journal of Social Psychology, 30, 323-334.

Ryder, A. G., Alden, L. E., \& Paulhus, D. L. (2000). Is acculturation unidimensional or bidimensional? A head-to-head comparison in the prediction of personality, selfidentity, and adjustment. Journal of Personality and Social Psychology, 79, 49-65.

Safdar, S., Struthers, W., \& van Oudenhoven, J. P. (2009). Acculturation of Iranians in the United States, the United Kingdom, and the Netherlands. Journal of Cross-Cultural Psychology, 40, 468-491.

Saguy, T., Tausch, N., Dovidio, J. F., \& Pratto, F. (2009). The irony of harmony. Psychological Science, 20(1), 114-121.

Sam, D. L. \& Berry, J. W. (Eds) (2006). Cambridge Handbook of Acculturation Psychology. Cambridge: Cambridge University Press.

Sani, F. (Ed.)(2008). Self continuity: Individual and collective perspectives. New York: Psychology Press. 
Sarrasin, O., Green, E.G.T., Fasel, N., Christ, O., Staerklé, C., \& Clémence A. (in press). Opposition to anti-racism laws across Swiss municipalities: A multilevel analysis. Political Psychology.

Scheepers, P., Gijsberts, M., \& Coenders, M. (2002). Ethnic exclusion in European countries. Public opposition to civil rights for legal migrants as a response to perceived ethnic threat. European Sociological Review, 18, 17-34.

Schlueter, E., \& Wagner, U. (2008). Regional differences matter: Examining the dual influence of the regional size of the Immigrant population on derogation of immigrants in Europe. International Journal of Comparative Sociology, 49, 153-173.

Schlueter, E., Schmidt, P., \& Wagner, U. (2008). Disentangling the causal relations of perceived group threat and outgroup derogation: Cross-national evidence from German and Russian panel surveys. European Sociological Review, 24, 567-581.

Schmid, K., Tausch, N., Hewstone, M., Hughes, J., \& Cairns, E. (2008). The effects of living in segregated vs. mixed areas in Northern Ireland: A simultaneous analysis of contact and threat effects in the context of micro-level neighbourhoods. International Journal of Conflict and Violence, 2, 56-71.

Schmitt, M. T. \& Branscombe, N. R. (2002). The meaning and consequences of perceived discrimination in disadvantaged and privileged social groups. In W. Stroebe \& M. Hewstone (Eds.), European Review of Social Psychology (Vol. 12, pp. 167-199). Chichester, England: Wiley.

Schneider, S. L. (2008). Anti-immigrant attitudes in Europe: Outgroup size and perceived ethnic threat. European Sociological Review, 24, 53-67.

Sears, D. O, \& Henry, P. J. (2005). Over thirty years later: A contemporary look at symbolic racism and its critics. In M. P. Zanna (Ed.), Advances in Experimental Social Psychology (pp. 95-150). New York: Academic Press. 
Sears, D. O., Citrin, J., Cheleden, S., \& Van Laar, C. (1999). Cultural diversity and multicultural politics: Is ethnic balkanization psychologically inevitable? In D. Prentice and D. T. Miller (Eds.), Cultural divides: Understanding and overcoming group conflict (pp. 35-79). New York: Russell Sage

Sears, D.O. \& Brown (in this handbook)

Sears, D. O., \& Funk, C. (1991). The role of self-interest in social and political attitudes. Advances in Experimental Psychology, 24, 1-91.

Semyonov, M., \& Glikman, A. (2009). Ethnic residential segregation, social contacts, and anti-minority attitudes in European societies. European Sociological Review, 25, 693708.

Semyonov, M., Raijman, R., \& Gorodzeisky, A. (2006). The rise of anti-foreigner sentiment in European societies, 1988-2000. American Sociological Review, 71, 426-449.

Semyonov, M., Raijman, R., Yom-Tov, A., \& Schmidt, P. (2004). Population size, perceived threat, and exclusion: A multiple-indicators analysis of attitudes toward foreigners in Germany. Social Science Research, 33, 681-701.

Sherif, M. (1967). Group conflict and cooperation: Their social psychology. London: Routledge \& Kegan Paul.

Sidanius, J., \& Pratto, F. (1999). Social Dominance: An intergroup theory of social hierarchy and oppression. New York: Cambridge University.

Sides, J., \& Citrin, J. (2007). European opinion about immigration: The role of identities, interests and information. British Journal of Political Science, 37, 477-504.

Simon, B. \& Ruhs, D. (2008). Identity and politicization among Turkish migrants in Germany: The role of dual identification. Journal of Personality and Social Psychology, 95, 1354-1366.

Smeekes, A., Verkuyten, M., \& Poppe, E. (2011). Mobilizing opposition towards Muslim 
immigrants: National identification and the representation of national history. British Journal of Social Psychology, 50, 265-280.

Snauwaert, B., Soenens, B., Vanbeselaere, N., \& Boen, F. (2003). When integration does not necessarily imply integration. Journal of Cross-Cultural Psychology, 34, 231-239.

Sniderman, P. M., Hagendoorn, L., \& Prior, M. (2004). Predisposing factors and situational triggers: Exclusionary reactions to immigrant minorities. American Political Science Review, 98, 35-49.

Spears, R., Jetten, J., \& Doosje, B. (2001). The (il)legitimacy of ingroup bias: From social reality to social resistance. In J. Jost \& B. Major (Eds.), The psychology of legitimacy. Emerging perspectives on ideology, justice and intergroup relations (pp. 332-362). Cambridge: Cambridge University Press.

Staerklé, C., Clémence, A., \& Spini, D. (2011). Social representations: A normative and dynamic intergroup approach. Political Psychology, 32, 759-768.

Staerklé, C., Sidanius, J., Green, E. G. T., \& Molina, L. (2010). Ethnic minority-majority asymmetry in national attitudes around the world: A multilevel analysis. Political Psychology, 31, 491-519.

Stephan, W. G., \& Renfro, C. L. (2003). The role of threat in intergroup relations. In D. M. Mackie \& E. R. Smith (Eds.), From prejudice to intergroup emotions. Differentiated reactions to social groups (pp. 191-207). New York: Psychology Press.

Stephan, W. G., \& Stephan, C. W. (1985). Intergroup anxiety. Journal of Social Issues, 41, 157-175.

Strabac, Z., \& Listhaug, O. (2008). Anti-Muslim prejudice in Europe: A multilevel analysis of survey data from 30 countries. Social Science Research, 37, 268-286.

Taylor, C. (1992). Multiculturalism and the politics of recognition. Princeton: Princeton University Press. 
Thomsen, L., Green, E.G. T., \& Sidanius, J. (2008). We will hunt them down: How social dominance orientation and right-wing authoritarianism fuel ethnic persecution of immigrants in fundamentally different ways. Journal of Experimental Social Psychology 44 (6): 1455-1464.

Thomas, W.I., \& Znaniecki, F. (1918). The Polish peasant in Europe and in America. Chicago: University of Chicago Press.

Turner, R. N., Hewstone, M., \& Voci, A. (2007). Reducing explicit and implicit prejudice via direct and extended contact: The mediating role of self-disclosure and intergroup anxiety. Journal of Personality and Social Psychology, 93, 369-388.

Van Oudenhoven, J. P., Prins, K. S., \& Buunk, B. P. (1998). Attitudes of majority and minority members towards adaptation of immigrants. European Journal of Social Psychology, 28, 995-1013.

Van Oudenhoven, J. P., Ward, C., \& Masgoret, A.-M. (2006). Patterns of relations between immigrants and host societies.. International Journal of Intercultural Relations, 30, 637-651.

Vedder, P., Sam, D. L., \& Liebkind, K. (2007). The acculturation and adaptation of Turkish adolescents in North-Western Europe. Applied Developmental Science, 11, 126 - 136.

Velasco Gonzalez, K., Verkuyten, M., Weesie, J., \& Poppe, E. (2008). Prejudice towards Muslims in the Netherlands: Testing integrated threat theory. British Journal of Social Psychology , 47, 667-685.

Verkuyten, M. ( 2005a). The social psychology of ethnic identity. (European Monographs in Social Psychology). Hove, UK: Psychology Press.

Verkuyten, M. (2005b). Ethnic group identification and group evaluation among minority and majority groups: Testing the multiculturalism hypothesis Journal of Personality and Social Psychology, 88, 121-138. 
Verkuyten, M. (2005c). Immigration discourses and their impact on multiculturalism: A discursive and experimental study. British Journal of Social Psychology, 44, 223-240.

Verkuyten, M. (2006). Multicultural recognition and ethnic minority rights: A social identity perspective. European Review of Social Psychology, 17, 148-184.

Verkuyten, M. (2007). Religious group identification and inter-religious relations: A study among Turkish-Dutch Muslims. Group Processes \& Intergroup Relations, 10, 341357.

Verkuyten, M. \& Brug, P. (2004). Multiculturalism and group status: The role of ethnic identification, group essentialism and Protestant ethic. European Journal of Social Psychology, 34, 647-661.

Verkuyten, M., \& Yildiz, A. A. (2006). The endorsement of minority rights: The role of group position, national context, and ideological beliefs. Political Psychology, 27, 527-548.

Verkuyten, M., \& Yildiz, A. A. (2009). Muslim immigrants and religious group feelings: selfidentification and attitudes among Sunni and Alevi Turkish-Dutch. Ethnic and Racial Studies, 32, $1121-1142$.

Voci, A., \& Hewstone, M. (2003). Intergroup contact and prejudice toward immigrants in italy: The mediational role of anxiety and the moderational role of group salience. Group Processes \& Intergroup Relations, 6, 37-54.

Wagner, U., Christ, O., Pettigrew, T. F., Stellmacher, J., \& Wolf, C. (2006). Prejudice and minority proportion: Contact instead of threat effects. Social Psychology Quarterly, 69, 380-390.

Weldon, S. A. (2006). The institutional context of tolerance for ethnic minorities: A comparative, multilevel analysis of western Europe. American Journal of Political Science, 50, 331-349.

Wilkes, R., Guppy, N., \& Farris, L. (2007). Right-wing parties and anti-foreigner sentiment in 
Europe. Comment on Semyonov, Raijman and Gorodzeisky. American Sociological Review, 72, 831-840.

Wills, M. (2010). Psychological research and immigration policy. Journal of Social Issues, 66, 825-836.

Wimmer, A. (2004). Does ethnicity matter? Social categories and personal networks in three Swiss immigrant neighborhoods. Ethnic and Racial Studies, 27, 1-36.

Wolsko, C., Park, B., \& Judd, C. (2006). Considering the tower of Babel: Correlates of assimilation and multiculturalism among ethnic minority and majority groups in the United States. Social Justice Research, 19, 277-306.

Wright, S. C., \& Lubensky, M. E. (2009). The struggle for social equality: Collective action versus prejudice reduction. In S. Demoulin, J.-P. Leyens \& J. F. Dovidio (Eds.), Intergroup misunderstandings: Impact of divergent social realities (pp. 291-310). New York: Psychology Press.

Zagefka, H., \& Brown, R. (2002). The relationship between acculturation strategies, relative fit and intergroup relations: immigrant-majority relations in Germany. European Journal of Social Psychology, 32, 171-188.

Zárate, M. A., Garcia, B., Garza, A. A., \& Hitlan, R. T. (2004). Cultural threat and perceived realistic group conflict as dual predictors of prejudice. Journal of Experimental Social Psychology, 40, 99-105.

Zick, A., Wagner, U., Van Dick, R., \& Petzel, T. (2001). Acculturation and prejudice in Germany: Majority and minority perspectives. Journal of Social Issues, 57, 541-557. 